\title{
Isotopic identification of nitrogen hotspots across natural terrestrial ecosystems
}

\author{
E. Bai ${ }^{1}$, B. Z. Houlton ${ }^{2}$, and Y. P. Wang ${ }^{3}$ \\ ${ }^{1}$ State Key Laboratory of Forest and Soil Ecology, Institute of Applied Ecology, Chinese Academy \\ of Sciences, Shenyang 110164, China \\ ${ }^{2}$ Department of Land, Air and Water Resources, University of California, Davis, California, USA \\ ${ }^{3}$ CSIRO Marine and Atmospheric Research and Centre for Australian Weather and Climate Research, \\ Aspendale VIC 3195, Victoria, Australia \\ Correspondence to: E. Bai (baie@iae.ac.cn)
}

Received: 8 November 2011 - Published in Biogeosciences Discuss.: 15 December 2011

Revised: 29 June 2012 - Accepted: 12 July 2012 - Published: 23 August 2012

\begin{abstract}
Nitrogen (N) influences local biological processes, ecosystem productivity, the composition of the atmospheric-climate system, and the human endeavour as a whole. Here we use natural variations in $\mathrm{N}$ isotopes, coupled with two models, to trace global pathways of $\mathrm{N}$ loss from the land to the water and atmosphere. We show that denitrification accounts for approximately $35 \%$ of total $\mathrm{N}$ losses from the natural soil, with $\mathrm{NO}, \mathrm{N}_{2} \mathrm{O}$, and $\mathrm{N}_{2}$ fluxes equal to $15.7 \pm 4.7 \mathrm{Tg} \mathrm{N} \mathrm{yr}^{-1}, 10.2 \pm 3.0 \mathrm{Tg} \mathrm{N} \mathrm{yr}^{-1}$, and $21.0 \pm 6.1 \mathrm{Tg} \mathrm{Nyr}^{-1}$, respectively. Our analysis points to tropical regions as the major "hotspot" of nitrogen export from the terrestrial biosphere, accounting for $71 \%$ of global $\mathrm{N}$ losses from the natural land surface. The poorly studied Congo Basin is further identified as one of the major natural sources of atmospheric $\mathrm{N}_{2} \mathrm{O}$. Extra-tropical areas, by contrast, lose a greater fraction of $\mathrm{N}$ via leaching pathways ( $\sim 77 \%$ of total $\mathrm{N}$ losses) than do tropical biomes, likely contributing to $\mathrm{N}$ limitations of $\mathrm{CO}_{2}$ uptake at higher latitudes. Our results provide an independent constraint on global models of the $\mathrm{N}$ cycle among different regions of the unfertilized biosphere.
\end{abstract}

\section{Introduction}

Nitrogen $(\mathrm{N})$ is essential to all life and affects many different aspects of the Earth system as a whole. At the molecular scale, for instance, $\mathrm{N}$ is a significant component of nucleic acids, protein and other biomolecules that regulate a suite of cell functions. At larger scales, $\mathrm{N}$ influences the climate system via its direct impact on climate forcing and indirectly via its role in constraining $\mathrm{CO}_{2}$ uptake and storage on land and in the sea (Fig. 1). Consequently, biogeochemists, climatologists, and ecologists are fundamentally interested in understanding how $\mathrm{N}$ cycles among Earth's biomes and across a spectrum space-time scales - especially in terms of how much $\mathrm{N}$ enters and leaves the biosphere along dissolved vs. gaseous paths.

However, two principal factors have greatly challenged this objective. First, $\mathrm{N}_{2}$ - likely the dominant gaseous $\mathrm{N}$ product of soil bacteria - is difficult to measure accurately because of the large background concentration of $\mathrm{N}_{2}$ in air (Scholefield et al., 1997; Swerts et al., 1995). This challenge has sparked controversies over the "missing N" in the global N budget (Galloway et al., 2004). Second, emissions of $\mathrm{NO}, \mathrm{N}_{2} \mathrm{O}$ or $\mathrm{N}_{2}$ can vary significantly in space and time; hence, scaling up field measurements, using either empirical or computational models, imparts large, unexplained errors in estimates of gaseous $\mathrm{N}$ emissions (Matson et al., 1989; Galloway et al., 2004; Scheer et al., 2009; Butterbach-Bahl et al., 2002; McClain et al., 2003; Groffman et al., 2009). Consequently, modelling has become an essential tool for estimation of $\mathrm{N}$ gas emissions at regional to global scales.

Boyer et al. (2006) reviewed current approaches for modelling terrestrial $\mathrm{N}$ gas fluxes at regional scales. The two basic approaches involve either mass-balance (Howarth et al., 1996) or simulation models, particularly DAYCENT (Parton et al., 1998), DNDC (denitrification-decomposition) 


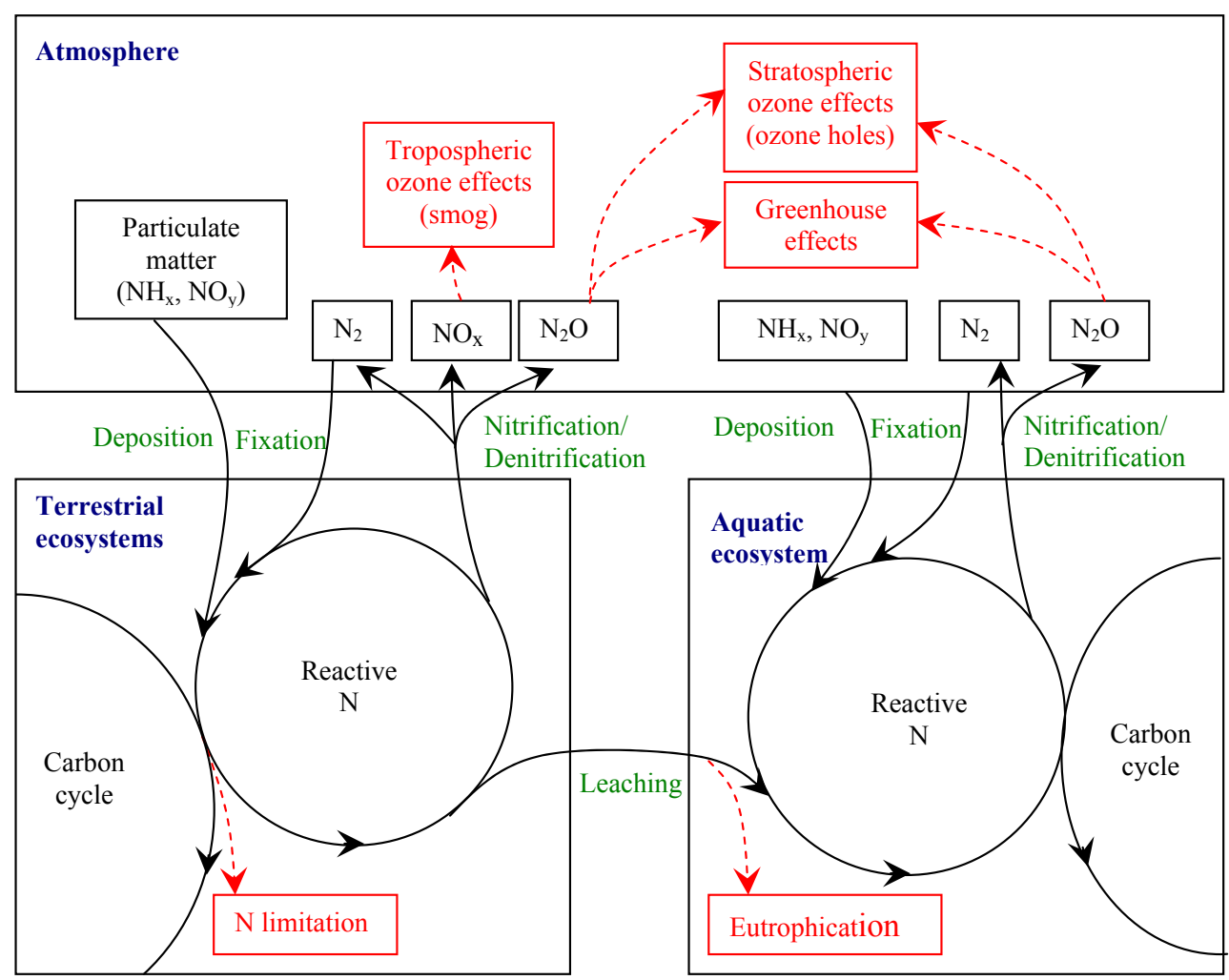

Fig. 1. Diagram of $\mathrm{N}$ cycling and its influences on global change.

(Li et al., 1992), CASA (Carnegie-Ames-Stanford) (Potter et al., 1996), EPIC (erosion-productivity impact calculator) (Williams et al., 1984), and INCA (integrated nitrogen in catchment) (Whitehead et al., 1998). These latter models build on various rate-controlling properties of denitrification such as climatic, soil, nutrient, and land use characteristics. They are generated to varying degrees from empirical measurements that are extrapolated from lab and field studies to ecosystems, regions and the globe. However, due to the complexities in $\mathrm{N}$ transformations, these models are generally highly parameterized and poorly constrained by observations that integrate large scales of space and time. In addition, it is difficult to obtain good estimates of many of the spatially heterogeneous variables used to constrain denitrification and some input data are not available at the global scale (Groffman et al., 2009).

Natural variations in $\mathrm{N}$ isotope abundance have provided insights into large-scale $\mathrm{N}$ cycling on land and in the sea (Amundson and Baisden, 2000; Houlton et al., 2006; Handley et al., 1999; Brenner et al., 2001; Amundson et al., 2003; Houlton and Bai, 2009; Bai and Houlton, 2009; Altabet et al., 1995; Sigman et al., 2003; Devol et al., 2006; Morford et al., 2011). The stable isotopes of $\mathrm{N},{ }^{15} \mathrm{~N}$ and ${ }^{14} \mathrm{~N}$ vary naturally in their abundance among biogenic materials owing to isotope fractionations, particularly kinetic ones, which are commonly associated with organisms' enzymatic preferences for isotopically light $\mathrm{N}\left({ }^{14} \mathrm{~N}\right)$ (Kendall, 1998). Within the terrestrial biosphere, coherent patterns in the $\mathrm{N}$ isotope composition of soils and ecosystems are observed across gradients in temperature, precipitation, and latitude (Handley et al., 1999; Amundson et al., 2003; Craine et al., 2009). Such ${ }^{15} \mathrm{~N} /{ }^{14} \mathrm{~N}$ patterns in total soil $\mathrm{N}$ pools reflect the dominant pathways by which $\mathrm{N}$ enters and leaves ecosystems (Amundson et al., 2003; Houlton et al., 2006; Bai and Houlton, 2009; Houlton and Bai, 2009). Houlton and Bai (2009) have previously developed an isotopic approach to partition the $\mathrm{N}$ losses between gaseous and leaching vectors for the natural land biosphere. However, their approach did not consider regionalscale variations in $\mathrm{N}$ loss fractions, fluxes or forms; rather it envisaged the natural terrestrial environment as a single vector.

Here we extend on the approach of Houlton and Bai (2009) by partitioning gaseous $\mathrm{N}$ losses into $\mathrm{NO}, \mathrm{N}_{2} \mathrm{O}$ and $\mathrm{N}_{2}$ across different sectors of the unfertilized land biosphere. This analysis aggregates several different model results at a spatial resolution of $0.5^{\circ} \times 0.5^{\circ}$ lat/long analyzed on a monthly time step to the steady state (Fig. 2). Two of the models are used to constrain the mass flux of $\mathrm{N}$ in each grid cell, based on previously published estimates of terrestrial $\mathrm{N}$ inputs, including $\mathrm{N}$ fixation (Wang and Houlton 2009) and $\mathrm{N}$ deposition (Lelieveld and Dentener, 2000). Two other models are used to partition $\mathrm{N}$ losses between hydrologic and gaseous 
pathways and the forms of gaseous $\mathrm{N}$ produced via denitrification (Fig. 2). The isotope model differs substantially from traditional techniques in that it does not explicitly consider controls such as climate, carbon, or $\mathrm{N}$ cycling rates; rather, total ecosystem ${ }^{15} \mathrm{~N} /{ }^{14} \mathrm{~N}$ ratios in each grid-cell integrate all such controls on $\mathrm{N}$ loss pathways (e.g. Hadley et al. 1999; Amundson et al., 2003; Houlton et al., 2006; Houlton and Bai 2009). Thus, we generate empirically centered constraints on the flux, form and uncertainty in $\mathrm{N}$ losses, against which traditional process-based models (for example, Bai and Houlton 2009) and satellite data can be independently examined (see Fig. 2).

\section{Materials and methods}

Our approach involves three phases (Fig. 2). First, we use previously published estimates of $\mathrm{N}$ fixation (Wang and Houlton, 2009) and N deposition (Lelieveld and Dentener, 2000) to force the total mass of $\mathrm{N}$ outputs at the global scale. Second, we use estimates of the $\mathrm{N}$ isotope composition of soil to constrain the proportion of $\mathrm{N}$ lost to denitrification vs. leaching paths across different terrestrial ecosystems. Third, we use a simple model to further partition denitrification gases into $\mathrm{N}$ gas fates, including $\mathrm{NO}, \mathrm{N}_{2} \mathrm{O}$ and $\mathrm{N}_{2}$. In the case of $\mathrm{NO}$, we compare the modelled results to satellite-based estimates of $\mathrm{NO}_{2}$ emissions over the continent of Africa. Finally, we analyze the sensitivities of our estimated $\mathrm{N}$ gaseous fluxes to key model parameters and the uncertainty of global denitrification using Monte Carlo simulation.

The spatial resolution is $0.5^{\circ} \times 0.5^{\circ}$ for both the isotope fractionation model and gas partitioning model. All input data were regridded to $0.5^{\circ} \times 0.5^{\circ}$ for the simulations in this study. Using the steady-state assumption, we first estimate the total $\mathrm{N}$ loss at $0.5^{\circ} \times 0.5^{\circ}$ spatial resolution globally from the $\mathrm{N}$ inputs of deposition and fixations, then partition the $\mathrm{N}$ loss between leaching and total gaseous loss using the isotope fractionation model. We further estimate the fractions of different $\mathrm{N}$ gaseous losses $\left(\mathrm{NO}_{2}, \mathrm{NO}, \mathrm{N}_{2} \mathrm{O}\right.$ and $\left.\mathrm{N}_{2}\right)$ using a $\mathrm{N}$ gas partitioning model that uses mean monthly volumetric soil water content at the top $1 \mathrm{~m}$ from 1948 to 2006 (see data sets below).

\subsection{Nitrogen isotope model}

$\mathrm{N}$ isotope ratios are presented in delta notation:

$\delta=\left[\left(R_{\text {sample }}-R_{\mathrm{STD}}\right) / R_{\mathrm{STD}}\right] \times 10^{3}$

where $R_{\text {sample }}$ is the ${ }^{15} \mathrm{~N} /{ }^{14} \mathrm{~N}$ ratio of the sample and $R_{\mathrm{STD}}$ is the ${ }^{15} \mathrm{~N} /{ }^{14} \mathrm{~N}$ ratio of the atmospheric dinitrogen.

Our $\mathrm{N}$ isotope model is based on the conceptual model of controls on whole-ecosystem ${ }^{15} \mathrm{~N} /{ }^{14} \mathrm{~N}$ (Houlton et al., 2006). Although plant uptake can discriminate against ${ }^{15} \mathrm{~N}$ when $\mathrm{N}$ is abundant (Evans, 2001), the expression of this isotope effect is not observed in many natural sites where $\mathrm{N}$ is scarce
(Houlton et al., 2007). More likely are isotope effects owing to mycorrhizal symbionts, which can deliver low ${ }^{15} \mathrm{~N} /{ }^{14} \mathrm{~N}$ compounds to hosts, potentially causing leaves to have a lower $\delta^{15} \mathrm{~N}$ than the soils on which plants rely (Hobbie and Hobbie, 2006; Craine et al., 2009). Nevertheless, regardless of any such isotope effect, plant and associated root symbionts return $\mathrm{N}$ to the soil with the same weighted $\delta^{15} \mathrm{~N}$ as that of $\mathrm{N}$ uptake as these systems approach the steady state. Therefore, under steady-state conditions, internal $\mathrm{N}$ cycling processes (plant uptake and microbial uptake) do not influence bulk soil ${ }^{15} \mathrm{~N} /{ }^{14} \mathrm{~N}$ ratios because they are recycling $\mathrm{N}$ as opposed to affecting overall $\mathrm{N}$ balances (Bai and Houlton, 2009; Brenner et al., 2001; Houlton et al., 2006). This lack of internal $\mathrm{N}$ cycle control on ${ }^{15} \mathrm{~N} /{ }^{14} \mathrm{~N}$ has been proven mathematically (Brenner et al., 2001; Amundson et al., 2003; Houlton et al., 2006; Bai and Houlton, 2009) and is supported by empirical observations across a broad range of climatic and ecosystems conditions (Bai and Houlton, 2009; Houlton et al., 2006; Houlton and Bai, 2009). Although further inquiry into potential plant and microbial recycling effects on ecosystem ${ }^{15} \mathrm{~N} /{ }^{14} \mathrm{~N}$ would be useful in general (see discussion), we here apply the steady-state assumption as a first approximation, consistent with other global biogeochemical modelling efforts (Potter et al., 1996; Bouwman et al., 2005a; Mayorga et al., 2010; Howarth et al., 1996). Thus, we focus on $\mathrm{N}$ inputs that occur via deposition and fixation and losses from soil along gaseous (ammonia-volatilization, nitrification, denitrification) ( $\left.f_{\text {gas all }}\right)$ and leaching pathways $\left(f_{\text {leaching }}\right)$. Hence, we derive the following set of equations:

$\delta^{15} N_{\text {soil }}=\delta^{15} N_{I}+\varepsilon_{\text {gas_all }} \times f_{\text {gas_all }}+\varepsilon_{L} \times f_{\text {leaching }}$

$f_{\text {gas_all }}+f_{\text {leaching }}=1$

where $\delta^{15} \mathrm{~N}_{\text {soil }}$ is the isotopic composition of bulk soil; $\delta^{15} \mathrm{~N}_{\mathrm{I}}$ is that of atmospheric inputs; and $\varepsilon_{L}$ and $\varepsilon_{\text {gas_all }}$ are the enrichment factors for leaching and gaseous losses, respectively $\left[\varepsilon(\% o)=\left({ }^{14} \mathrm{k} /{ }^{15} \mathrm{k}-1\right) \cdot 1000\right]$, where $k$ is a rate constant.

Gaseous loss pathways include nitrification/denitrification processes and ammonia volatilization. In our model, denitrification includes both denitrification and nitrifier denitrification, since these bacterial groups fractionate $\mathrm{N}$ isotopes similarly (Sutka et al., 2006). From this point forward, "N gas" refers to collective denitrification; we account for the magnitude and isotopic impact of ammonia volatilization using results from previous models. We further partitioned $f_{\text {gasall }}$ to $f_{\text {gas }}$ and $f_{\mathrm{NH} 3}$ :

$\varepsilon_{\text {gas_all }} \times f_{\text {gas_all }}=\varepsilon_{G} \times f_{\text {gas }}+\varepsilon_{\mathrm{NH} 3} \times f_{\mathrm{NH} 3} ;$

$f_{\text {gas }}+f_{\mathrm{NH} 3}=f_{\text {gas_all }}$.

From (2), (3), (4), and (5) one gets

$f_{\text {gas }}=\frac{\delta^{15} N_{\text {soil }}-\delta^{15} N_{I}-\left(\varepsilon_{\mathrm{NH} 3}-\varepsilon_{L}\right) \times f_{\mathrm{NH} 3}-\varepsilon_{L}}{\varepsilon_{G}-\varepsilon_{L}}$. 


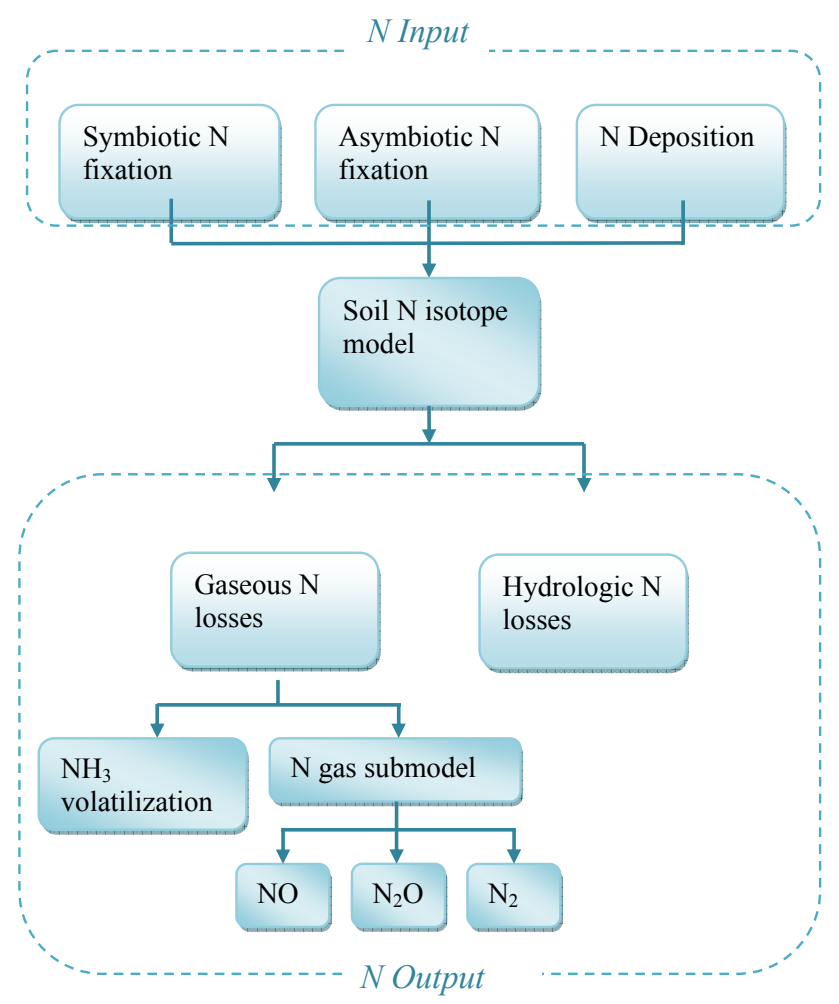

Fig. 2. Model structure.

The $\mathrm{N}$ inputs to natural ecosystems via fixation and deposition have relatively low ${ }^{15} \mathrm{~N} /{ }^{14} \mathrm{~N}$ ratios that do not appear to vary substantially from system to system. $\mathrm{N}_{2}$ fixation, for example, does not appear to fractionate $\mathrm{N}_{2}$ in air; its $\delta^{15} \mathrm{~N}$ is close to $0 \%$ (Boddey et al., 2000; Yoneyama et al., 1986; Shearer and Kohl, 1986). In addition, the isotopic composition of deposited $\mathrm{N}$ is typically in the range of $-3 \%$ to $3 \%$ (Buzek et al., 1998; Handley et al., 1999; Freyer et al., 1996; Houlton et al., 2006), with bulk nitrate deposition across various latitudes, altitudes, climates and biomes averaging $\delta^{15} \mathrm{~N}$ of $-1.5 \%$ o (Houlton and Bai, 2009). While ammonium and dissolved organic $\mathrm{N}$ compounds can also be deposited, their ${ }^{15} \mathrm{~N} /{ }^{14} \mathrm{~N}$ ratios either overlap with or are somewhat ${ }^{15} \mathrm{~N}$-depleted relative to that of nitrate in bulk precipitation (Cornell et al., 1995; Heaton et al., 1997; Houlton et al., 2006). Combining both fixation and deposition inputs, $\delta^{15} \mathrm{~N}_{\mathrm{I}}$ is thus in the range of $-1.5 \%$ o to $0 \%$, in accord with previous syntheses (i.e. $-2 \%$ to $1 \%$; Handley et al., 1999). We do not consider rock $\mathrm{N}$ inputs, though this may be an important term for future $\mathrm{N}$ isotopic modelling efforts (Morford et al., 2011).

Although $\mathrm{N}$ leaching pathways could remove low $\delta^{15} \mathrm{~N}$ compounds from soil $\left(\varepsilon_{L}\right)$ in principle, empirical data suggest that the discrimination is small. Shi(1992) found the fractionation factor of losses by dissolved $\mathrm{NH}_{4}^{+}-\mathrm{N}$ was $0 \%$ to $0.5 \%$. Feuerstein et al. (1997) reported that $\delta^{15} \mathrm{~N}$ of DON was $1-2 \%$ lower than coexisting particulate organic matter in surface water of the Great Lakes. Densmore et al. (2000) noted the difference between $\delta^{15} \mathrm{~N}$ of soil total $\mathrm{N}$ and $\delta^{15} \mathrm{~N}$ of leachable $\mathrm{N}$ was within $1 \%$ at Irwine and Bicycle basins in California. Houlton et al. (2006) found that the difference between the $\delta^{15} \mathrm{~N}$ stream total dissolved $\mathrm{N}$ and soil total $\mathrm{N}$ was no more than $1-2 \%$ across a suite of Hawaiian forests. Finally, Houlton and Bai (2009) found that the $\delta^{15} \mathrm{~N}$ of nitrate in small drainage streams was very close to that of soil particulate matter from Arctic to tropical biomes, with an integrated $\varepsilon_{L}$ equal to $0.85 \%$. This latter analysis pointed to uniformly small isotope effect expression of nitrification at the scale of entire ecosystems. Thus, we use a ${ }^{15} \mathrm{~N}$ discrimination of $1 \%$ of $\varepsilon_{L}$ in our model parameterization scheme, and $0-5 \%$ in our model uncertainty analysis (see below).

Gaseous $\mathrm{N}$ losses substantially discriminate against ${ }^{15} \mathrm{~N}$ along three major paths - denitrification, nitrification, and ammonia volatilization. Isotope fractionation during ammonia volatilization is high $\left(\varepsilon_{\mathrm{NH} 3}, 29 \%\right.$ based on Hogberg (1997)) and has been shown to elevate the $\delta^{15} \mathrm{~N}$ of heavily grazed terrestrial ecosystems; however, ammonia volatilization from soils under natural vegetation accounts for a small fraction of $\mathrm{N}$ losses, less than $5 \%$ of total gaseous losses (Bouwman et al., 1997). Consequently, this process plays a minor role in elevating $\delta^{15} \mathrm{~N}_{\text {soil }}$ globally. By contrast, bacterial pathways of gaseous $\mathrm{N}$ removal lead to significant ${ }^{15} \mathrm{~N}$ enrichments - and with a flux that is large enough to substantially elevate the $\delta^{15} \mathrm{~N}$ of soil above atmospheric $\mathrm{N}$ inputs. Indeed, the average isotope effect of denitrification on nitrate is substantial in both pure culture $(\sim 20 \%$ ) (Wellman et al., 1968) and in natural soil communities $(\sim 16 \%$ o $)$ (Houlton and Bai, 2009). Consistent with empirical studies, we assume that nitrifier and denitrifier gases impart similar fractionations of $\mathrm{N}$ isotopes (Yoshida, 1988; JinuntuyaNortman et al., 2008), and we use a combined enrichment factor $\left(\varepsilon_{G}\right)$ to represent the isotope effect of both processes on terrestrial ${ }^{15} \mathrm{~N} /{ }^{14} \mathrm{~N}$. We use an $\varepsilon_{G}$ of $16 \%$ in our model parameterization, allowing it to vary between $16-20 \%$ in our model uncertainty analysis (see below). We did not account for further (i.e. values below 16\%o) isotopic underexpression of denitrification, as this seems to be an important factor at very high rainfall levels (e.g. MAP $>4 \mathrm{~m}$ ), regimes that constitute a very small $(<1 \%)$ area of global land environment (Bai and Houlton, 2009).

Finally, geographic distributions of $\delta^{15} \mathrm{~N}_{\text {soil }}$ are relatively well known, with many compilations pointing to similar patterns across Earth's major ecosystems (Amundson et al., 2003; Handley et al., 1999; Martinelli et al., 1999). To estimate $\delta^{15} \mathrm{~N}$ at the scale of regions and biomes, we use the large-scale (i.e. regions, biomes) assessment in Amundson et al. (2003), which is based on empirical modelling. The range of $\delta^{15} \mathrm{~N}_{\text {soil }}$ globally is $-2.1 \%$ o to $10.4 \%$, generally higher than $\delta^{15} \mathrm{~N}_{\mathrm{I}}$, indicating that $\delta^{15} \mathrm{~N}_{\text {soil }}$ is elevated compared to external $\mathrm{N}$ inputs. The standard variation of the estimate is 2.11 , and the uncertainty is $40.7 \%$. Although this approach may introduce errors at small scales, it reasonably 
approximates shifts in $\delta^{15} \mathrm{~N}$ across temperate vs. tropical biomes to within $\sim 1$ or $2 \%$ of empirical observations (Houlton and Bai, 2009). Thus, we use this model to integrate soil $\delta^{15} \mathrm{~N}$ across ecosystems, realizing that it may slightly underestimate the actual magnitude of terrestrial ${ }^{15} \mathrm{~N}$ enrichment, pointing to the conservative nature of our isotopic approach overall. It should be noticed that above equations represent long-term equilibrium values rather than short-term $(<$ decade) responses and our model is the integration of all isotopic-fractionating emissions over the course of ecosystem development (a few decades to centuries).

\section{2 $\mathrm{N}$ deposition and $\mathrm{N}$ fixation}

When the isotope model is coupled with $\mathrm{N}$ input models, $f_{\text {gas }}$ can be converted to fluxes at steady state:

$N_{\text {gas }}=\left(N_{\text {fixation }}+N_{\text {deposition }}\right) \times f_{\text {gas }}$.

Global symbiotic $\mathrm{N}_{2}$ fixation $\left(1 \times 1^{\circ}\right)$ is generated from the CASACNP model (Wang et al., 2007; Houlton et al., 2008; Wang and Houlton, 2009; Wang et al., 2010). Asymbiotic $\mathrm{N}_{2}$ fixation is based on the biome average reported in Cleveland et al. (1999) and the global biome classification in CASACNP (Wang et al., 2007; Wang et al., 2010). Global $\mathrm{N}$ deposition $\left(5^{\circ} \times 3.75^{\circ}\right)$ is generated from a three dimensional chemistry-transport model run in the early 1990s (Lelieveld and Dentener, 2000). The total global N input to natural ecosystems is equal to $129 \mathrm{Tg} \mathrm{Nyr}^{-1}$ in our model analysis. Global ammonia volatilization fluxes for natural soils are based on the biome averages as reported in Bouwman et al. (1997).

\subsection{N gas production submodel}

We use an index of water-filled pore space (WFPS, \%) to represent the "holes" in the conceptual $\mathrm{N}$ flux pipe (Davidson, 1991), simulating the effects of $\mathrm{O}_{2}$ availability on gaseous $\mathrm{N}$ emissions. Nitrification and nitrifier-denitrification are the main $\mathrm{N}$ gas producing processes when WFPS is low and denitrification increases in importance when WFPS is more than $60 \%$ (Bateman and Baggs, 2005). When WFPS exceeds $80 \%, \mathrm{~N}_{2}$ becomes the major gaseous $\mathrm{N}$ form (Davidson, 1991). Based on empirical findings (Bateman and Baggs, 2005) and previous modelling of the relationship between WFPS of soil and relative fluxes of $\mathrm{N}$ gases (Davidson, 1991; Potter et al., 1996), we use an index of WFPS to develop our "gas partitioning curve" (Fig. 3).

After Potter et al. (1996), the index of WFPS is unitless and is estimated by

$\mathrm{WFPS}=(\mathrm{E}+\mathrm{FC}) / \mathrm{PS} \quad \mathrm{E}>0$

$\mathrm{WFPS}=\mathrm{W} / \mathrm{PS} \quad \mathrm{E}=0$

where $\mathrm{FC}$ is soil field capacity $\left(\mathrm{m} \mathrm{m}^{-1}\right)$; PS is soil pore space capacity $\left(\mathrm{m} \mathrm{m}^{-1}\right)$; $\mathrm{W}$ is monthly mean soil water content $\left(\mathrm{m} \mathrm{m}^{-1}\right)$; and $\mathrm{E}$ is excess moisture input (i.e. monthly runoff) $\left(\mathrm{m} \mathrm{m}^{-1}\right)$. Where WFPS exceeds $100 \%, 100 \%$ is used in the modelling.

We compiled observations of $\mathrm{N}_{2} \mathrm{O} /\left(\mathrm{NO}+\mathrm{N}_{2} \mathrm{O}\right)$ and $\mathrm{N}_{2} \mathrm{O} /\left(\mathrm{N}_{2} \mathrm{O}+\mathrm{N}_{2}\right)$ as a function of water-filled pore space (WFPS) from various lab and field studies (Supplement Table 1) in order to validate our $\mathrm{N}$ gas submodel (Fig. 4). Agreement between modelled and observed ratios is measured using root-mean-squared error (RMSE):

RMSE $=\sqrt{\frac{1}{N} \sum_{i=1}^{N}\left(M_{i}-O_{i}\right)^{2}}$

where $M_{\mathrm{I}}$ is modelled $\mathrm{N}_{2} \mathrm{O} /\left(\mathrm{NO}+\mathrm{N}_{2} \mathrm{O}\right)$ or $\mathrm{N}_{2} \mathrm{O} /\left(\mathrm{N}_{2} \mathrm{O}+\mathrm{N}_{2}\right)$ ratio, $O_{\mathrm{I}}$ is the corresponding observed ratio, and $\mathrm{N}$ is the total number of observations. RMSE is equal to 0.20 for $\mathrm{N}_{2} \mathrm{O} /\left(\mathrm{NO}+\mathrm{N}_{2} \mathrm{O}\right)$ ratios $(n=46)$ and 0.42 for $\mathrm{N}_{2} \mathrm{O} /\left(\mathrm{N}_{2} \mathrm{O}+\mathrm{N}_{2}\right)$ ratios $(n=69)$. When WFPS is low, NO is the major form of gaseous $\mathrm{N}$ loss; at higher WFPS, more $\mathrm{N}_{2} \mathrm{O}$ is produced; when WFPS $>70 \%$, due to increasing anaerobic conditions, $\mathrm{N}_{2}$ production increases rapidly and becomes the dominate form of gaseous N (Fig. 4). We used the coefficient of variation (CV) of the global total denitrification flux to calculate the modelled range (mean $\pm \mathrm{CV}$ ) of each gas form (see above).

\subsection{Seasonal variations of NO in Africa}

Seasonal variations of NO in Africa were estimated using our model and GOMES satellite observations (Jaegle et al., 2004). Mean annual total $\mathrm{N}$ gaseous fluxes were first apportioned equally to each month, and then partitioned to $\mathrm{NO}, \mathrm{N}_{2} \mathrm{O}$ and $\mathrm{N}_{2}$ fluxes based on monthly mean WFPS (see above). Modelled NO in January, June, and August (Fig. 5a) reflects the recent 50-yr-mean (1948-2008) monthly variations in WFPS.

\subsection{Data sets}

After Amundson et al. (2003), we estimate soil $\delta^{15} \mathrm{~N}$ by applying multiple regression models to climate data:

$\delta^{15} N_{\text {soil }}=0.2048 \times \mathrm{MAT}-0.0012 \times \mathrm{MAP}+4.32$.

The model is based on empirical relationships observed across various climosequences, spanning different biomes and climatic conditions. Mean annual temperature (MAT) and precipitation $(\mathrm{MAP})$ data $\left(0.5^{\circ} \times 0.5^{\circ}\right)$ are from Willmott and Matsuura (2000). The global unfertilized surface $\left(0.1^{\circ} \times 0.1^{\circ}\right)$ is based on the biome classification scheme of VUB and VITO, derived from a full year cycle (1998-1999) of 10-daily composites of SPOT-VEGETATION (www. geosuccess.net/Geosuccess). Areas classified as croplands, urban and build-up, and cropland and natural vegetation mosaic, are considered as cultivated and urban land.

Soil moisture and runoff data are from Fan and van den Dool (2004), available on a $0.5^{\circ} \times 0.5^{\circ}$ monthly basis for 
Table 1. Comparison of global estimations of $\mathrm{N}$ gas productions by $\mathrm{N}$ isotope model with previously published empirical and modelling studies (NO fluxes are soil-surface emissions without canopy effects).

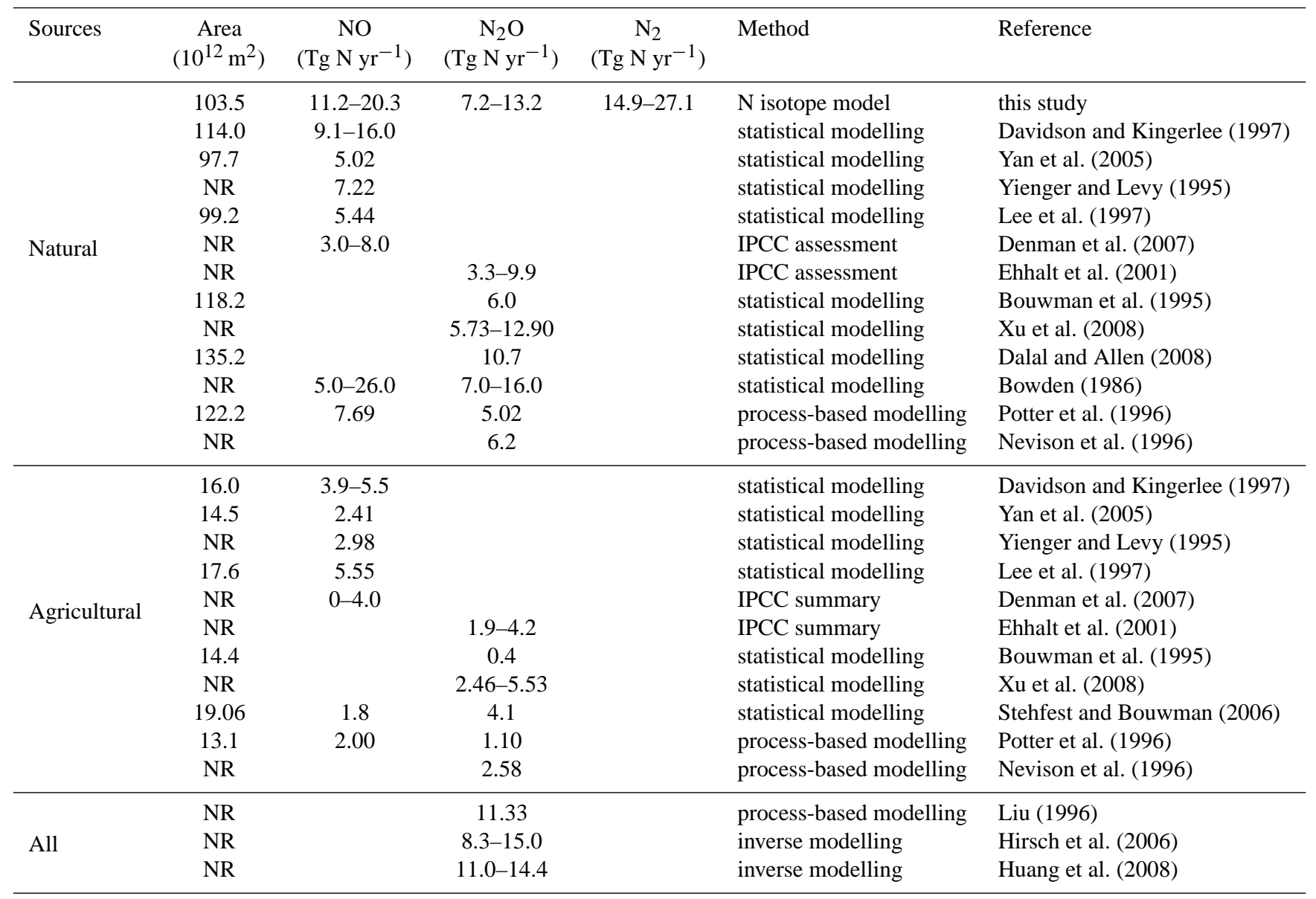

NR: Not reported

year 1948 to the present, based on a one-layer "tippingbucket" model (Mintz and Serafini, 1981; Huang et al., 1996) that uses the spatially explicit estimates of soil properties based on IGBP soil texture attributes. Global soil field capacity (FC) and soil texture data are from Webb et al. (2000) $\left(1^{\circ} \times 1^{\circ}\right)$. Soil pore space capacity (PS) is computed from IGBP soil texture (see Eq. 7 in Saxton et al. (1986)).

\subsection{Sensitivity and uncertainty analyses}

Sensitivity analyses are conducted by evaluating the response in global denitrification fluxes resulting from changes in model input parameters at a level of $\pm 10 \%$. Results of this analysis indicate a sensitivity range from 1.3 to $11.9 \%$ (Fig. 6). Global denitrification is most sensitive to soil $\delta^{15} \mathrm{~N}$ $\left(\delta^{15} \mathrm{~N}_{\text {soil }}\right)$ and the effective isotope effect of denitrification $\left(\varepsilon_{G}\right): \mathrm{a}+10 \%$ increase in either $\delta^{15} \mathrm{~N}_{\text {soil }}$ or $\varepsilon_{G}$ results in $+11.9 \%$ or $-11.9 \%$ variation in denitrification, respectively. A $10 \%$ increase in the $\mathrm{N}$ input flux $\left(\mathrm{N}_{\text {input }}\right)$ corresponds to a $10 \%$ increase in $\mathrm{N}$ outputs as implied by our steady- state

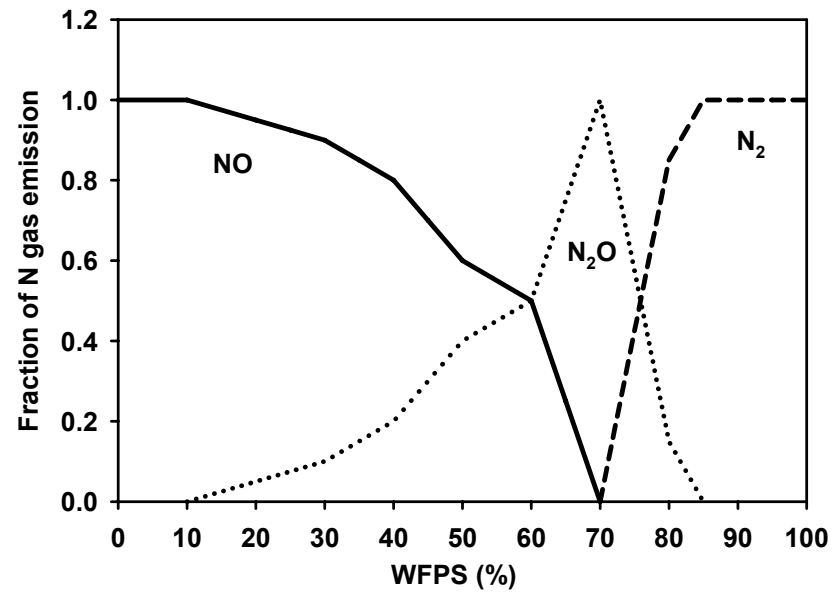

Fig. 3. Model of $\mathrm{N}$ gas production as a function of WFPS (waterfilled pore space, \%). The solid line represents NO; short dashed line represents $\mathrm{N}_{2} \mathrm{O}$ fraction; and long dashed line represents $\mathrm{N}_{2}$. 


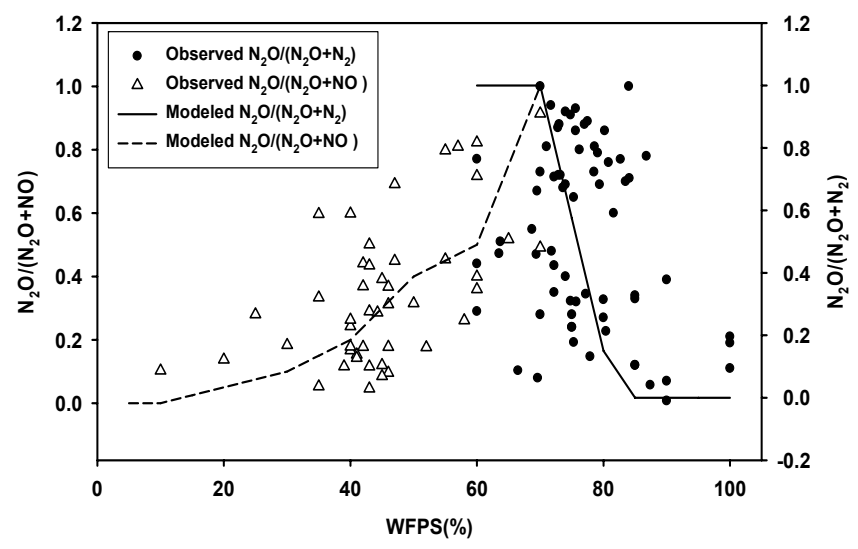

Fig. 4. Comparison of the ratios of $\mathrm{N}_{2} \mathrm{O}-\mathrm{N} /\left(\mathrm{N}_{2} \mathrm{O}-\mathrm{N}+\mathrm{NO}-\mathrm{N}\right)$ and $\mathrm{N}_{2} \mathrm{O}-\mathrm{N} /\left(\mathrm{N}_{2} \mathrm{O}-\mathrm{N}+\mathrm{N}_{2}-\mathrm{N}\right)$ from field measurements (points) with ratios predicted by the gas partitioning model (lines). Additional information on the field measurements is presented in Supplement Table 1.

assumption. Therefore, additional constraints on $\delta^{15} \mathrm{~N}_{\text {soil }}$ and $\varepsilon_{G}$ would most improve the model's accuracy.

We used Monte Carlo methodology to estimate uncertainties in global denitrification. Assuming that the errors in $\delta^{15} \mathrm{~N}_{\text {soil }}, \delta^{15} \mathrm{~N}_{\mathrm{I}}, f_{\mathrm{NH} 3}$, and $\mathrm{N}_{\text {input }}$ are normally distributed with a coefficient of variation of $50 \%$, and the errors of $\mathrm{N}$ isotope enrichment factors are uniformly distributed within the range of $25-35 \%$ for $\varepsilon_{\mathrm{NH} 3}, 16-20 \%$ for $\varepsilon_{G}$, and 0 $5 \%$ for $\varepsilon_{L}$, we randomly sampled 10000 sets of these seven parameters from the prescribed probability distributions to estimate the mean and uncertainty of denitrification for each grid cell at $0.5^{\circ} \times 0.5^{\circ}$ resolution.

The mean global denitrification rate $\left(\mu_{T}\right)$ was calculated as the sum of the means of all grid cells. For the uncertainty, we considered spatial correlations of errors among adjacent grid cells. We first performed variogram analysis (Isaaks and Srivastava, 1989), which indicated that gaseous emissions were correlated within a range distance of 84 cells (ca. $4662 \mathrm{~km}$ ). Based on this correlogram, we then estimated a correlation coefficient between two grid cells (cell $(i, j)$ and cell $(k, l))\left(\rho_{i j, k l}\right)$ :

$\rho_{i j, k l}=1-\frac{\gamma(h)}{\mathrm{VAR}}$

where $\gamma(h)$ is the semi-variogram of the two grid cells with a distance of $h$, and VAR is the total variance of all grid cells. We used an exponential model to describe the variation of $\gamma(h)$ with $h$. That is

$\gamma(h)=C \mathrm{o}+C \mathrm{~s} \times\left(1-e^{-(3 h / a)}\right)$

where $C_{\mathrm{o}}$ is the nugget (= 0.10 for our data), $C_{\mathrm{S}}$ is the partial sill ( $=0.36$ for our data), and $a$ is the range ( $=42$ decimal degree for our data) of the variogram model.
The standard deviation of the mean global denitrification rate (i.e. $\sigma_{T}$ ) was calculated as

$\sigma_{T}^{2}=\sum_{i=1}^{N} \sum_{j=1}^{M} \sum_{k=1}^{N} \sum_{l=1}^{M} \sigma_{i j} \times \sigma_{k l} \times \rho_{i j, k l}$

where $i, k, j$, and $l$ refer to row and column numbers of the global grid cells; $N$ and $M$ refer to total latitudinal and longitudinal cells, respectively.

The uncertainty in the global denitrification rate is expressed as the coefficient of variation (i.e. $\sigma_{T} / \mu_{T}$ ), and the range is expressed at the $68 \%$ confidence interval (i.e. [ $\mu_{T}-$ $\left.\left.\sigma_{T}, \mu_{T}+\sigma_{T}\right]\right)$.

\section{Results}

\subsection{N loss pathways}

Our model indicates that $35 \%$ of all $\mathrm{N}$ inputs to the natural unfertilized land biosphere is lost to denitrification each year. This agrees with results from Houlton and Bai (2009), in which the $\mathrm{N}$ isotope composition of the entire natural land biosphere suggested that about $1 / 3$ of $\mathrm{N}$ deposition and fixation are lost back to the atmosphere via soil denitrification pathways. It is also reasonably consistent with the estimate of Seitzinger et al. (2006) of $44 \%$, which is based on numerical simulation models. Thus, our spatially explicit analysis using $\mathrm{N}$ stable isotope constraints on the global $\mathrm{N}$ budget points to a substantial role for denitrification gases in removing $\mathrm{N}$ from unfertilized land, helping to close the overall global $\mathrm{N}$ budget.

Perhaps more important, across the terrestrial biosphere, $f_{\text {gas }}$ varies substantially. Specifically, our analysis suggests that gaseous $\mathrm{N}$ losses vary from $0 \%$ to $69 \%$ of total natural $\mathrm{N}$ inputs across temperate vs. tropical latitudes (Fig. 7a). The highest gas loss fractions are associated with desert sites, where precipitation « potential evapotranspiration and hydrologic leaching is minimal. Although the absolute fluxes in these areas may be low due to low $\mathrm{N}$ inputs, gaseous $\mathrm{N}$ efflux is estimated to be high relative to leaching, consistent with previous analyses (Galbally et al., 2008; Hartley and Schlesinger, 2000). In contrast, $f_{\text {gas }}$ decreases at higher latitudes, where limited quantities of nitrate, low NPP, and low temperatures $(T)$ constrain denitrification for most of the year. In these environments, leaching ( $\left.f_{\text {leaching }}\right)$ is the dominate vector of $\mathrm{N}$ loss. Globally, we estimate that $65 \%$ of total $\mathrm{N}$ losses occur via leaching, consistent with previous estimates (i.e. $72 \%$ ) for unfertilized terrestrial ecosystems (Bouwman et al., 2005b).

Our results also point to marked spatial clustering in the magnitude of denitrification within the natural terrestrial biosphere, with a global denitrification flux equal to $46.9 \pm 13.6 \mathrm{Tg} \mathrm{N} \mathrm{yr}^{-1}$, within the range of previous estimates $\left(58 \mathrm{Tg} \mathrm{N} \mathrm{yr}^{-1}\right.$ ) (Seitzinger et al., 2006). The highest fluxes are inferred for central Africa, South America, and Southeast 


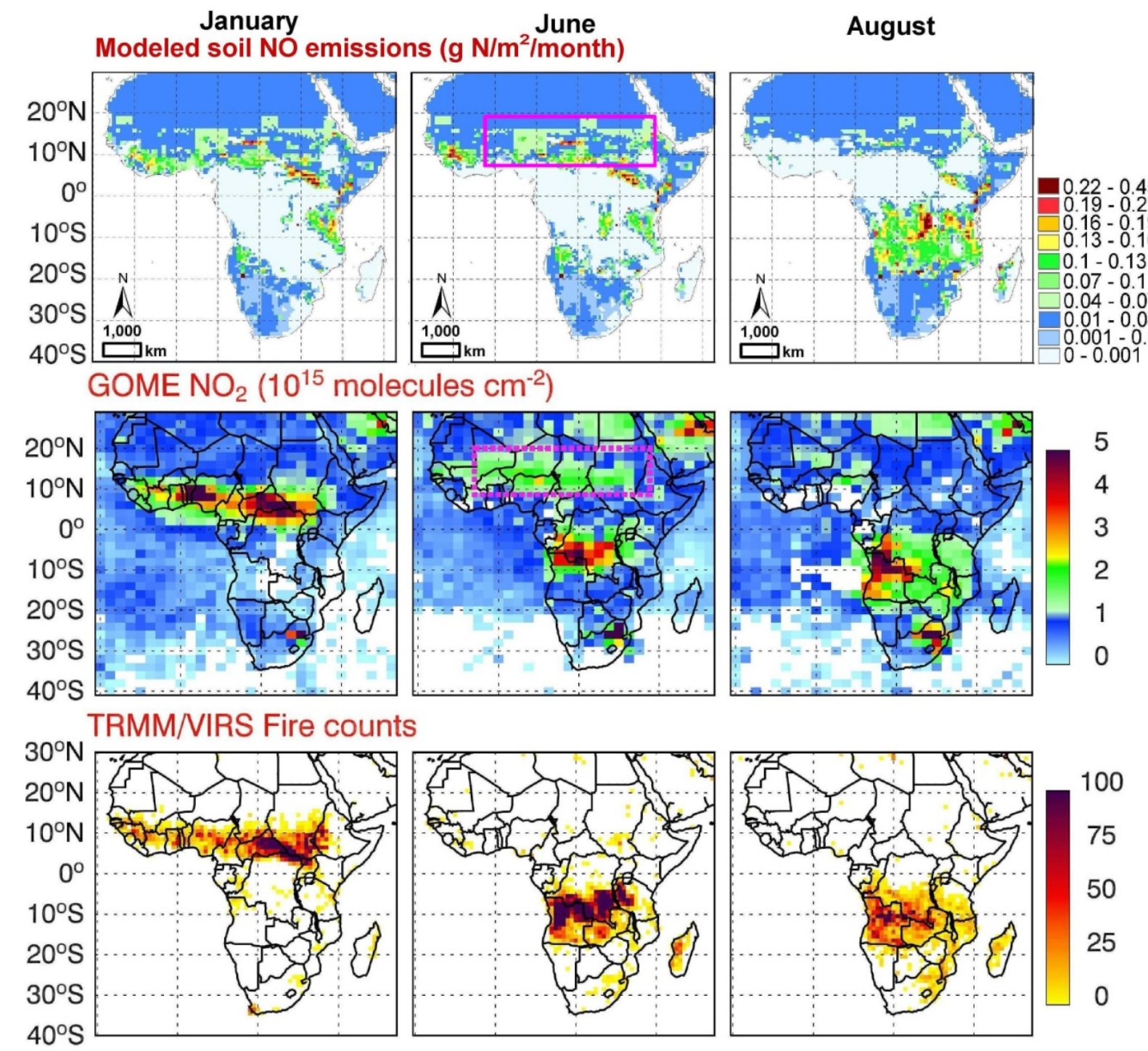

Fig. 5. Comparison of modelled soil $\mathrm{NO}$ emissions $\left(\mathrm{g} \mathrm{N} \mathrm{m}^{-2}\right.$ month ${ }^{-1}$ ) (a) with space-based observations of $\mathrm{NO}_{2}$ column concentrations $\left(10^{15}\right.$ molecules $\left.\mathrm{cm}^{-2}\right)$ as reported in Jaegle et al. (2004) (b) and fire counts (c) as observed by the visible and infrared scanner on board the TRMM satellite (Jaegle et al., 2004) over Africa for January, June and August, 2000. The pink rectangle shows the area with unexpectedly high level of $\mathrm{NO}_{2}$ (b) during June, which was not caused by fire or industrial emissions based on the fire count map (c); rather, soil microbial $\mathrm{NO}_{\mathrm{x}}$ pulses following the onset of rainfall over vast areas of dry soil, a notion confirmed by our model simulations (a).

Asia, where the combination of warm temperatures, moist soil conditions, and high $\mathrm{N}$ availability favours high rates of soil microbial activity (Fig. 7b). This agrees with previous work pointing to high potential for denitrification in moist tropical sites (Potter et al., 1996; Galloway et al., 2004). Monte Carlo analysis reveals a coefficient of variation (CV) of $29 \%$ on our estimates for global natural denitrification fluxes.

In terms of dissolved pathways of $\mathrm{N}$ loss, we estimate that $85.7 \pm 24.8 \mathrm{Tg}$ of dissolved $\mathrm{N}$ compounds leach through the plant rooting zone in unfertilized areas annually. Southern United States, northern South America, central Africa, and southern Asia display the largest leaching fluxes due to a combination of high $\mathrm{N}$ inputs and high precipitation amounts (Fig. 7c). Below the plant rooting zone $(0-50 \mathrm{~cm})$, leached $\mathrm{N}$ (especially nitrate) may be further denitrified as it enters ground water and streams (Seitzinger et al., 2006). While the fate of this $\mathrm{N}$ is beyond the scope of this study, our results provide an independent estimate of dissolved $\mathrm{N}$ losses that can be incorporated into future studies of denitrification along the soil-river continuum. For example, our modelled spatial pattern of $\mathrm{N}$ leaching is similar to that of DIN yield predicted by NEWS-DIN (Dumont et al., 2005). Further, leaching is important beyond its role as a vehicle of $\mathrm{N}$ removal from the land: it strongly influences the productivity 


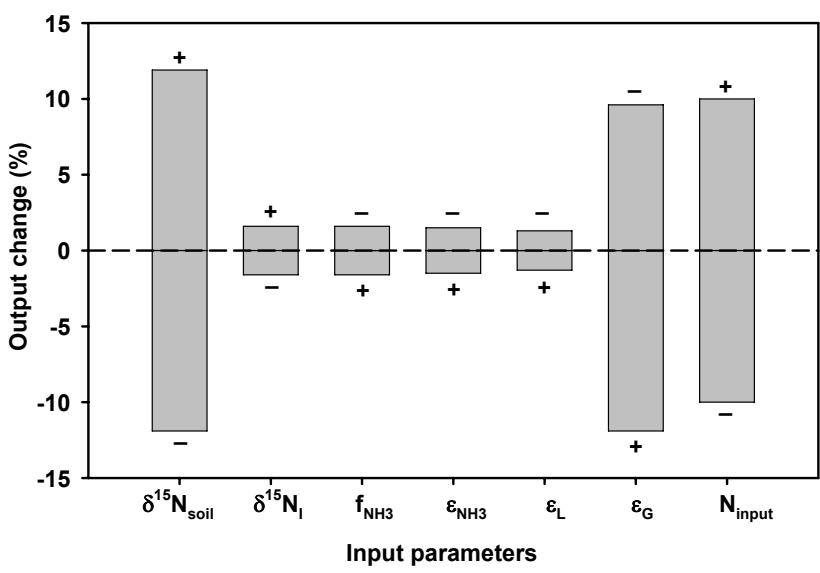

Fig. 6. Sensitivity of denitrification to different input parameters. "+" and "-" represent a $10 \%$ increase and $10 \%$ decrease in the input parameter, respectively.

of the coastal ecosystems and contributes to coastal hypoxia and anoxia.

\subsection{Gaseous $\mathbf{N}$ forms}

Our model integrates multiple data sets and several submodels, which is common for global-scale biogeochemical cycles due to large spatial and temporal integration (Charria et al., 2008; Schaldac and Pries, 2008; Thornton et al., 2009). Uncertainty in our model includes both model assumptions and model input parameters. In particular, we assume ecosystem isotope balance, whereby internal $\mathrm{N}$ cycling processes plant uptake, microbial uptake - do not influence bulk soil ${ }^{15} \mathrm{~N} /{ }^{14} \mathrm{~N}$ ratios (Amundson et al., 2003; Houlton et al., 2006; Bai and Houlton, 2009). This assumption seems to be valid at the scale of decades to centuries for most natural sites (Amundson et al., 2003); modern rates of $\mathrm{N}$ accumulation would have at most changed soil $\mathrm{N}$ pools $<0.1 \%$ over the past 100 years, implying negligible $\mathrm{N}$ accumulation effects on our isotopic calculations (Houlton and Bai, 2009). The steady-state assumption may be less valid in sites where relatively frequent and hot fires can lead to transient imbalances in $\mathrm{N}$ - especially on short time scales (Aranibar et al., 2003) (see below on importance of fire in $\mathrm{N}$ losses). Moreover, we use an empirically derived model to estimate soil $\delta^{15} \mathrm{~N}$ across global ecosystems and this imparts errors in our assessment of $\delta^{15} \mathrm{~N}$, especially at sub-grid scales. This is an important area for future work - more data on the $\delta^{15} \mathrm{~N}$ of soil across ecosystems. Nevertheless, we note that the approach we used to estimate soil $\delta^{15} \mathrm{~N}$ is able to capture shifts across temperate to tropical biomes, typically within about $1 \%$ of actual measurements (Houlton and Bai, 2009).

We estimate that, on average, $0.152 \pm 0.044 \mathrm{~g} \mathrm{~N} \mathrm{~m}^{-2} \mathrm{yr}^{-1}$ are lost to microbial NO production in the natural terrestrial soil (Table 1, Fig. 8a). Globally, the geographic area that is free from agriculture and major land cover transforma- tion is equal to $103.510^{12} \mathrm{~m}^{2}$ (based on VUB and VITO). Applying this area to our NO production rates, we calculate that $11.2-20.3 \mathrm{Tg} \mathrm{Nyr}^{-1}$ are emitted as $\mathrm{NO}$ from unfertilized land globally. This estimate is significantly higher than natural $\mathrm{NO}$ emissions (3-8 $\mathrm{Tg} \mathrm{Nyr}^{-1}$ ) as summarized in the Inter-governmental Panel on Climate Change's (IPCC) fourth assessment report (AR4) (Denman et al., 2007). Combining our estimate of natural NO emissions with that of cropland and managed grassland (Stehfest and Bouwman, 2006) (i.e. $1.8 \mathrm{Tg} \mathrm{Nyr}^{-1}$ ), we calculate a total $\mathrm{NO}$ flux of $13.0-22.1 \mathrm{Tg} \mathrm{N} \mathrm{yr}^{-1}$ for the entire terrestrial biosphere (i.e. fertilized plus unfertilized). This falls between those of most process (Potter et al., 1996) $\left(9.7 \mathrm{Tg} \mathrm{N} \mathrm{yr}^{-1}\right.$ ) and empirically based models (Davidson and Kingerlee, 1997) $\left(21.1 \mathrm{Tg} \mathrm{Nyr}^{-1}\right.$ ) (Table 1), but is higher than some estimates reported in the literature $\left(5-8 \mathrm{Tg} \mathrm{N} \mathrm{yr}^{-1}\right)$ (Yan et al., 2005; Yienger and Levy, 1995; Lee et al., 1997) (Table 1).

Regionally, highest NO emissions are simulated for mesic to dry tropical environments (Fig. 8a). Among the continents, Africa emerges as the largest source for NO in the natural terrestrial biosphere $\left(0.213-0.657 \mathrm{~g} \mathrm{~N} \mathrm{~m}^{-2} \mathrm{yr}^{-1}\right.$, Table 2). Our model simulates high NO emissions in tropical savanna/woodland environments $\left(0.267-0.711 \mathrm{~g} \mathrm{~N} \mathrm{~m}^{-2} \mathrm{yr}^{-1}\right.$ Table 2), while tundra falls at the low end of the worldwide NO spectrum $\left(0-0.007 \mathrm{~g} \mathrm{~N} \mathrm{~m}^{-2} \mathrm{yr}^{-1}\right.$ Table 2). Nitric oxide fluxes vary from $0.023-0.055 \mathrm{~g} \mathrm{~N} \mathrm{~m}^{-2} \mathrm{yr}^{-1}$ for temperate forest sites, in agreement with empirical data (Supplement Table 2). In global grasslands, we estimate microbial NO emissions between $0.101-0.179 \mathrm{~g} \mathrm{~N} \mathrm{~m}^{-2} \mathrm{yr}^{-1}$, or near the upper bound of previously published data (Supplement Table 2).

Importantly, the rate of emission of NO from the soil is higher than the flux to the atmosphere, owing to scavenging of NO by canopy vegetation (Bakwin et al., 1990). Nitric oxide is often quickly oxidized to $\mathrm{NO}_{2}$ upon emission, and can be absorbed onto vegetation surfaces, reducing the total amount of $\mathrm{NO}_{\mathrm{x}}$ that escapes to the atmosphere (Davidson and Kingerlee, 1997). Using leaf absorption factors (Yienger and Levy, 1995), we suggest that net emission of NO from unfertilized terrestrial ecosystems may be reduced by up to $10 \mathrm{Tg} \mathrm{N} \mathrm{yr}^{-1}$. Comparing our modelled spatial and temporal variations of soil surface $\mathrm{NO}$ emissions to satellite mapping of space-based observation of $\mathrm{NO}_{2}$ in Africa (Jaegle et al., 2004) (Fig. 5), we find that both soil microbial activities and fire activity are responsible for the high levels of atmospheric $\mathrm{NO}_{2}$ between $0^{\circ}$ to $10^{\circ} \mathrm{N}$ latitude in January. In contrast, the unexpectedly high level of $\mathrm{NO}_{2}$ above the Sahel region during June (shown in the pink rectangle in Fig. 5) is not caused by fire or industrial emissions; rather, Jaegle et al. (2004) speculated that this represented microbial $\mathrm{NO}_{\mathrm{x}}$ pulses following the onset of rainfall over vast areas of dry soil, a notion confirmed by our model simulations (Fig. 5a). Thus, our isotope-based approach appears to integrate broadscale dynamism in microbial gaseous $\mathrm{N}$ production rates. 

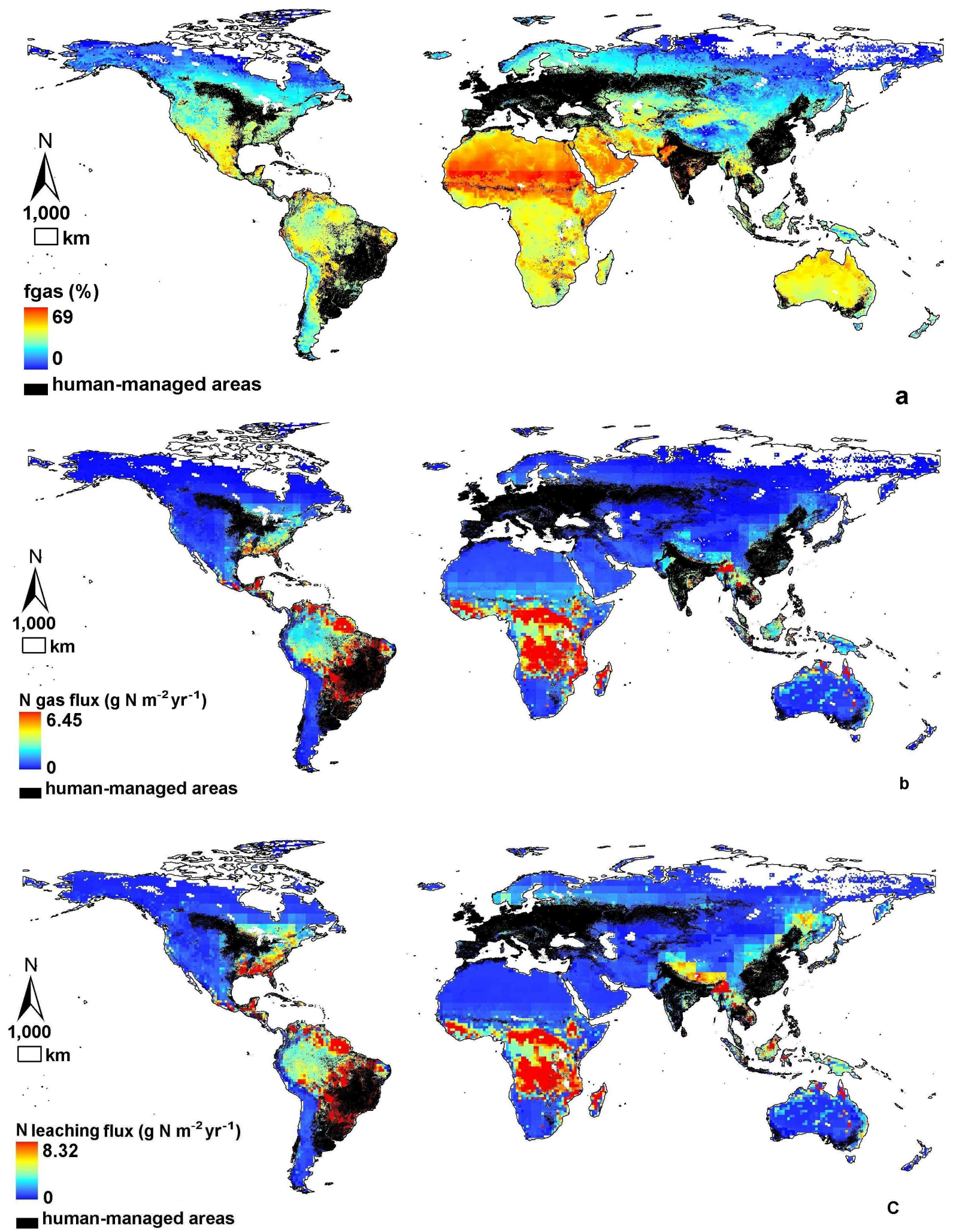

Fig. 7. Global patterns of fraction of gaseous $\mathrm{N}$ losses $\left(f_{\text {gas }}\right)(\mathbf{a})$, total gaseous $\mathrm{N}$ flux (b), and total leaching $\mathrm{N}$ flux (c) from unfertilized soils. 

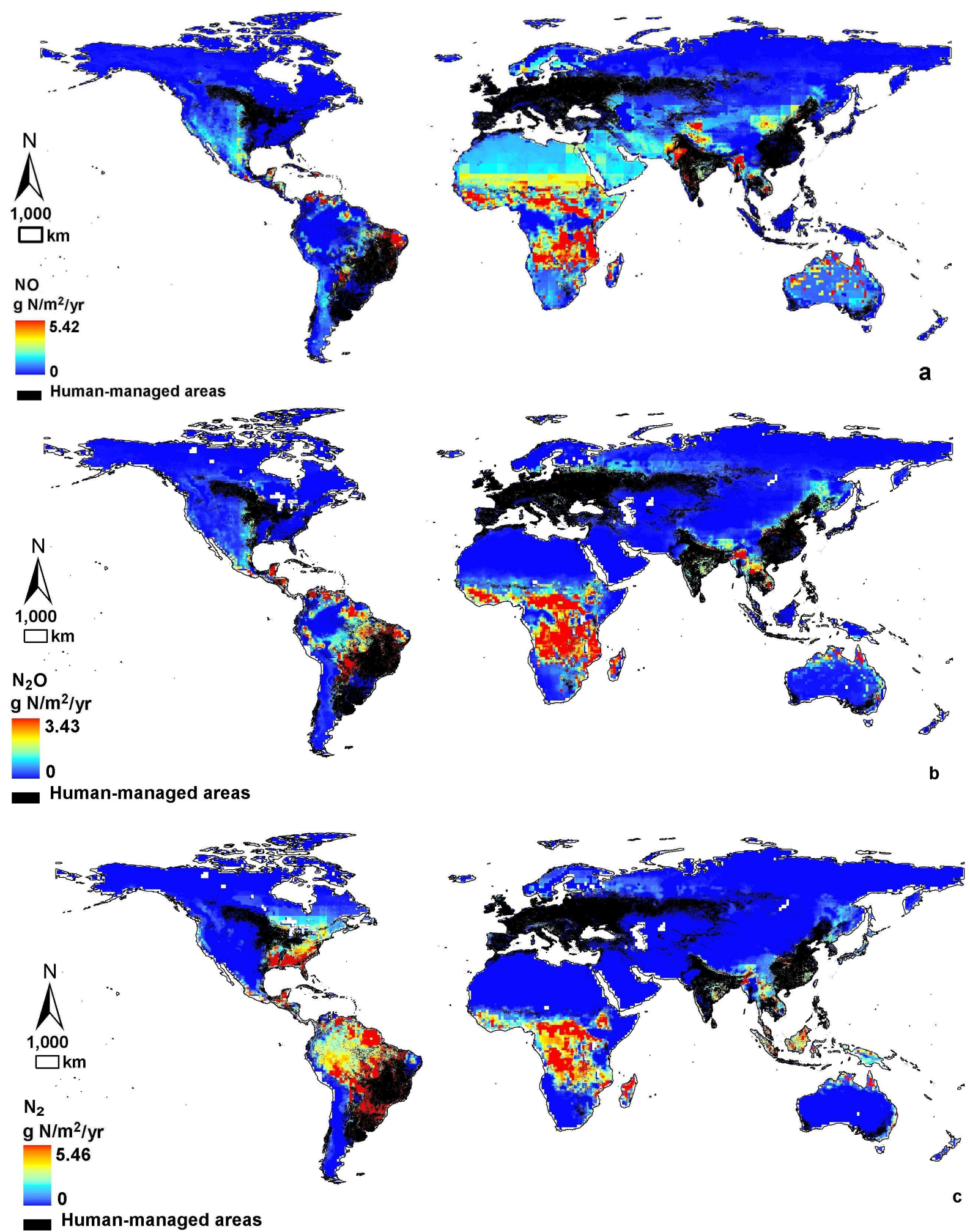

Fig. 8. Global patterns of $\mathrm{NO}(\mathbf{a}), \mathrm{N}_{2} \mathrm{O}\left(\right.$ (b), and $\mathrm{N}_{2}$ (c) from unfertilized soils. 
Table 2. Modelled results of regional N gas fluxes from soil denitrification.

\begin{tabular}{lcccc}
\hline \multirow{2}{*}{ Region } & Area $\left(10^{12} \mathrm{~m}^{2}\right)$ & \multicolumn{2}{c}{ Modelled N gas flux $\left(\mathrm{g} \mathrm{N} \mathrm{m}^{-2} \mathrm{yr}^{-1}\right)$} \\
& & $\mathrm{NO}$ & $\mathrm{N}_{2} \mathrm{O}$ & $\mathrm{N}_{2}$ \\
\hline Closed tropical forest & 9.0 & $0.099-0.229$ & $0.180-0.418$ & $0.602-1.396$ \\
Tropical rainforests & 9.2 & $0.095-0.217$ & $0.176-0.400$ & $0.610-1.390$ \\
Tropical savanna/woodland & 17.6 & $0.267-0.711$ & $0.150-0.398$ & $0.210-0.560$ \\
Brazilian Amazon forest & 5.5 & $0.067-0.285$ & $0.129-0.553$ & $0.406-1.734$ \\
Grassland/steppe & 22.3 & $0.101-0.179$ & $0.037-0.065$ & $0.028-0.050$ \\
Temperate/boreal forest & 21.1 & $0.023-0.055$ & $0.029-0.069$ & $0.104-0.244$ \\
Deserts and semi-deserts & 16.2 & $0.120-0.266$ & $0.003-0.007$ & $0.001-0.003$ \\
Chihuahuan Desert & 0.005 & $0.020-0.323$ & $0.003-0.049$ & 0.000 \\
Tundra & 10.7 & $0.000-0.007$ & $0.000-0.007$ & $0.000-0.010$ \\
Africa $\left(18^{\circ} \mathrm{N}-30^{\circ} \mathrm{S}\right)$ & 16.0 & $0.213-0.657$ & $0.165-0.507$ & $0.239-0.737$ \\
European forest & 3.0 & $0.026-0.118$ & $0.042-0.184$ & $0.038-0.162$ \\
United States & 5.33 & $0.023-0.119$ & $0.008-0.044$ & $0.106-0.544$ \\
\hline
\end{tabular}

For $\mathrm{N}_{2} \mathrm{O}$, we estimate that $7.2-13.2 \mathrm{Tg} \mathrm{N} \mathrm{yr}^{-1}$ of this potent greenhouse gas are emitted from natural soil microbes worldwide (Table 1, Fig. 8b). Bouwman et al. (1995) estimated $6.8 \mathrm{Tg} \mathrm{N} \mathrm{yr}^{-1}$ global pre-agricultural $\mathrm{N}_{2} \mathrm{O}$ emissions based on a simple empirical model, while the IPCC adopted value of 3.3-9.9 $\mathrm{Tg} \mathrm{N} \mathrm{yr}^{-1} \mathrm{~N}_{2} \mathrm{O}$ emissions from soils under natural vegetations in their 2001 report (Ehhalt et al., 2001). When our results are combined with the $\mathrm{N}_{2} \mathrm{O}$ efflux associated with fertilized cropland and managed grassland (4.1 $\mathrm{Tg} \mathrm{N} \mathrm{yr}^{-1}$ ) (Stehfest and Bouwman, 2006), we estimate a natural soil sourced global $\mathrm{N}_{2} \mathrm{O}$ flux between 11.3-

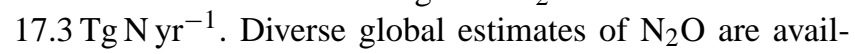
able via process-based, statistical, or inverse models; they (Huang et al., 2008; Nevison et al., 1996; Ehhalt et al., 2001; Bouwman et al., 1995; Xu et al., 2008; Dalal and Allen, 2008; Bowden, 1986; Potter et al., 1996; Liu, 1996; Hirsch et al., 2006) generally vary from $10.6 \mathrm{Tg} \mathrm{N} \mathrm{yr}^{-1}$ to $15 \mathrm{Tg} \mathrm{N} \mathrm{yr}^{-1}$ (Table 1). Our isotope-based model independently confirms this range of estimates of global $\mathrm{N}_{2} \mathrm{O}$ fluxes from natural soils.

Across the terrestrial biosphere, our model identifies moist tropical areas, such as the east Amazon Basin, central Africa, and northern Australia, as natural hotspots of bacterial $\mathrm{N}_{2} \mathrm{O}$ production (Fig. 8b). Specifically, we estimate that natural tropical rainforest and savanna biomes account for $77 \%$ of global natural $\mathrm{N}_{2} \mathrm{O}$ emissions. Tropical rainforests have the highest potential for $\mathrm{N}_{2} \mathrm{O}$ production (0.176-0.400 $\mathrm{g} \mathrm{N} \mathrm{m}^{-2} \mathrm{yr}^{-1}$ Table 2), whereas, similar to NO, tundra has the lowest $\left(0-0.007 \mathrm{~g} \mathrm{~N} \mathrm{~m}^{-2} \mathrm{yr}^{-1}\right.$ Table 2). Previous models have reported a mean range of $0.12-0.29 \mathrm{~g} \mathrm{~N} \mathrm{~m}^{-2} \mathrm{yr}^{-1}$ for $\mathrm{N}_{2} \mathrm{O}$ emissions from tropical forests (Matson and Vitousek, 1990; Bowden, 1986; Dalal and Allen, 2008; Potter et al., 1996) and a mean range of $0.022-0.068 \mathrm{~g} \mathrm{~N} \mathrm{~m}^{-2} \mathrm{yr}^{-1} \mathrm{~N}_{2} \mathrm{O}$ emissions from temperate forests (Dalal and Allen, 2008; Stehfest and Bouwman, 2006). Our results fall within this range - ex- cept for tropical savanna where we estimate higher $\mathrm{N}_{2} \mathrm{O}$ fluxes $\left(0.150-0.398 \mathrm{~g} \mathrm{~N} \mathrm{~m}^{-2} \mathrm{yr}^{-1}\right)$ than empirically (Dalal and Allen, 2008) and process-based (Potter et al., 1996) models. Our model may overestimate this flux, because firecaused $\mathrm{N}$ losses are not considered. For example, Olivier et al. (1998) estimated that $4.8 \mathrm{Tg} \mathrm{N} \mathrm{yr}^{-1}$ are removed by savanna fires, or approximately $62 \%$ of total fire-induced $\mathrm{N}$ gas emissions in the terrestrial biosphere. Globally, fire removes a modest amount of $\mathrm{N}\left(7.7 \mathrm{Tg} \mathrm{N} \mathrm{yr}^{-1}\right), \sim 5.8 \%$ of total $\mathrm{N}$ inputs (Olivier et al., 1998).

Finally, to our knowledge, we here provide the first-ever simulations of the global spatial pattern of natural soil $\mathrm{N}_{2}$ emissions, widely believed to be the dominant biogenic form of gaseous $\mathrm{N}$ on Earth. We estimate that 14.9-27.1 $\mathrm{Tg} \mathrm{N} \mathrm{yr}^{-1}$ are denitrified to atmospheric $\mathrm{N}_{2}$ in the unfertilized soil. According to our model, soil $\mathrm{N}_{2}$ originates mainly in southeast North America, north South America, central Africa, and Southeast Asia (Fig. 8c); anaerobic environments caused by high precipitation and poor soil drainage in these areas favour $\mathrm{N}_{2}$ production (Galloway et al., 2004). In contrast, dry and low $\mathrm{N}$ throughput environments have uniformly low $\mathrm{N}_{2}$ production potentials (Fig. 8c).

Due to methodological limitations, very few studies have assessed soil $\mathrm{N}_{2}$ fluxes in the field. Recently, Schlesinger (2009) compiled all of the available data on $\mathrm{N}_{2} \mathrm{O}-\mathrm{N} /\left(\mathrm{N}_{2} \mathrm{O}\right.$ $+\mathrm{N}_{2}$ )-N reported for terrestrial ecosystems under natural vegetation, with a mean fraction of 0.51 for grassland $(n=4), 0.41$ for forest $(n=14)$, and 1.0 for desert $(n=$ 1). Our model simulates an $\mathrm{N}_{2} \mathrm{O}-\mathrm{N} /\left(\mathrm{N}_{2} \mathrm{O}+\mathrm{N}_{2}\right)-\mathrm{N}$ ratio of 0.22 for tropical and temperate forest, 0.43 for tropical savanna/woodland, 0.57 for grassland, and 0.71 for desert biomes - all of which fit generally with Schlesinger's compilation (Schlesinger, 2009). In moist tropical forest, the high water availability and periods of extended anaerobiosis in soil, and high NPP and $\mathrm{N}$ cycling rates, favour low $\mathrm{N}_{2} \mathrm{O}-\mathrm{N} /\left(\mathrm{N}_{2} \mathrm{O}+\mathrm{N}_{2}\right)-\mathrm{N}$ ratios. In temperate forests, 
$\mathrm{N}_{2} \mathrm{O}-\mathrm{N} /\left(\mathrm{N}_{2} \mathrm{O}+\mathrm{N}_{2}\right)-\mathrm{N}$ ratios are generally low and extremely variable. For example, Wolf and Brumme (2003) reported $\mathrm{N}_{2} \mathrm{O}-\mathrm{N} /\left(\mathrm{N}_{2} \mathrm{O}+\mathrm{N}_{2}\right)-\mathrm{N}$ ratios ranging between 0.19 to 0.85 in beech forest with different mineral soils; Merrill and Zak (1992) found much higher values $(0.63-0.98)$ in upland forest in Michigan and a $\mathrm{N}_{2} \mathrm{O}-\mathrm{N} /\left(\mathrm{N}_{2} \mathrm{O}+\mathrm{N}_{2}\right)-\mathrm{N}$ ratio of 0.25 under swampy forest conditions. Dannenmann et al. (2008) observed a $\mathrm{N}_{2} \mathrm{O}-\mathrm{N} /\left(\mathrm{N}_{2} \mathrm{O}+\mathrm{N}_{2}\right)-\mathrm{N}$ ratio of 0.23 when water holding capacity (WHC) was $48-55 \%$, while the ratio dropped to 0.03 when WHC was $62-84 \%$.

\section{Discussion}

Our results point to tropical ecosystems as the global $\mathrm{N}$ cycling hotspot within the natural land surface. This agrees with field-based evidence (Vitousek, 1984;Hedin et al., 2009) and implies a potential coupling between natural paths of fixation (Houlton et al., 2008) and denitrification within this biome, similar to those couplings observed for the global open ocean (Deutsch et al., 2007). Future studies on $\mathrm{N}_{2}$ fixation and denitrification (and their couplings) in tropical forests are critical for understanding the integrated Earth-climate system and the magnitude and direction of carbon (C) exchanges between tropical biomes and the atmosphere.

Accurate partitioning of $\mathrm{N}$ losses along denitrification vs. leaching vectors is fundamental to understanding $\mathrm{C}$ and $\mathrm{N}$ couplings in the terrestrial biosphere. The response of $\mathrm{N}$ limited ecosystem to increasing $\left[\mathrm{CO}_{2}\right]$ depends partly on $\mathrm{N}$ loss responses to increasing $\left[\mathrm{CO}_{2}\right]$ in the future. Losses of DON compounds are substrate-independent (Hedin et al., 2003) and therefore less likely to change with increasing $\left[\mathrm{CO}_{2}\right]$ (Rastetter et al., 2005) than are $\mathrm{N}$ losses via nitrate leaching and denitrification that depends on available $\mathrm{N}$ substrates; denitrification in particular might be expected to decrease in response to progressive $\mathrm{N}$-limitation. Our study reveals that leaching is a greater fraction of $\mathrm{N}$ losses $(\sim 77 \%)$ at high latitudes, in contrast to the tropics where denitrification (leaching $=58 \%$ ) contributes more to the $\mathrm{N}$ economy of natural ecosystems. These results agree with empirical studies pointing to substantial DON losses from both boreal and unpolluted temperate forests and high denitrification rates in tropical sites (Seitzinger et al., 2006; Neff et al., 2003). We postulate that loss-driven $\mathrm{N}$ limitation will persist longer at high latitudes than other sectors of the terrestrial biosphere.

Global biogeochemical models have been used to study the change of nutrient limitation under future climate and higher $\left[\mathrm{CO}_{2}\right]$ conditions (Sokolov et al., 2008; Thornton et al., 2009; Zaehle et al., 2010a), but the spatial pattern of $\mathrm{N}$ limitation and its response to increased warming and $\left[\mathrm{CO}_{2}\right]$ is uncertain. For example, N limitation of tropical NPP is expected in one model (Thornton et al., 2009), whereas another model suggests that temperate and boreal forests will exhibit more profound symptoms of progressive $\mathrm{N}$ limitation than tropical forests in the future (Zaehle et al., 2010b). Global models of $\mathrm{C}$ and $\mathrm{N}$ cycles are poorly constrained (Wang et al., 2010); uncertainties in their predictions are expected to be high, but yet to be quantified. The spatially explicit estimates of $\mathrm{N}$ losses from this study can provide an important constraint for benchmarking the performance of global biogeochemical models under present conditions. Additional work on the $\mathrm{N}$ isotope composition of natural ecosystems, coupled with examination for transient effects where appropriate, would not only advance our approach further, but would also be useful for ground-truthing global models.

Our isotope-based approach considers interactions between soil microbial processes, climate and soil conditions over large spatial scales thereby providing a novel and independent constraint against which empirically and processbased models and inverse chemical transport analyses can be evaluated. Our isotope-based approach points to high NO emissions in Africa and high $\mathrm{N}_{2}$ emissions in Southeast USA, areas where very few measurements have been made. Incorporating spatial and temporal complexities (so-called "hotspots and hot moments") into the $\mathrm{N}$ cycle is considered the biggest challenge in denitrification research (Groffman et al., 2009). Previous studies have used models that were calibrated locally and extrapolated globally, introducing unquantifiable uncertainties into estimates of denitrification. Episodic emissions of $\mathrm{NO}$ and $\mathrm{N}_{2} \mathrm{O}$ in the arid and semiarid region are known to account for a significant fraction of total $\mathrm{N}$ loss (Hartley and Schlesinger, 2000), for example, and these losses are poorly simulated by most global models, whereas our model integrates all isotopic-fractionating emissions including episodic pulses of $\mathrm{NO}$ and $\mathrm{N}_{2} \mathrm{O}$ over a long period ( $>$ decade). The similarities between our modelled results and satellite observations of $\mathrm{NO}_{2}$ and newly identified hot spots of $\mathrm{N}$ emissions point to the power of our $\mathrm{N}$ isotope model at large scales.

Our modelled maps provide a reference for future studies. For example, our map (Fig. 8b) points to the Congo Basin in Africa as one of the dominant natural sources of $\mathrm{N}_{2} \mathrm{O}-$ a potent greenhouse gas (Fig. 1) and ozone-depleting agent (Ravishankara et al., 2009) - while there are almost no published data on $\mathrm{N}_{2} \mathrm{O}$ fluxes from this region. Most published data on $\mathrm{N}_{2} \mathrm{O}$ fluxes in the tropics are from South and Central American forests, with a few data from Southeast Asia and Northwest Australia. Thus, continued advancement on such issues as climate change and stratospheric ozone would seem to benefit from empirical investigations of the old-world tropics.

The spatial patterns of $\mathrm{N}_{2}$ emissions we describe are crucial for understanding $\mathrm{N}$ dynamics of the Earth system. Soil $\mathrm{N}_{2}$ is considered the most important pathway by which $\mathrm{N}$ is returned from the soil to the atmosphere (Schlesinger, 2009; Galloway et al., 2004). Our results support the common belief that $\mathrm{N}_{2}$ emissions account for a significant fraction of the "missing N" (Schlesinger, 2009) in the global N cycle, and provide the first-ever quantitative predictions of global patterns of $\mathrm{N}_{2}$ fluxes among terrestrial ecosystems. 
Our model can be improved with additional information, observations and experiments. In particular, knowledge on isotope fractionations via gaseous $\mathrm{N}$ losses is clearly warranted, since they can vary across different ecosystems and conditions; our sensitivity analyses (Fig. 6) indicate that our $\mathrm{N}$ loss fractions are most sensitive to variation in $\delta^{15} \mathrm{~N}$ $\left(\delta^{15} \mathrm{~N}_{\text {soil }}\right)$ and the isotope effect of denitrification $\left(\varepsilon_{\mathrm{den}}\right)$. This points to the importance of a deeper understanding of isotope effect expression and additional measurements of soil $\delta^{15} \mathrm{~N}$. In addition, more information on the influence of soil properties such as soil texture, soil water availability on $\mathrm{N}$ gas partitioning would increase the robustness of our model. Further, uncertainties in $\mathrm{N}_{2}$ fixation models are difficult to assess and are probably high, although they are the best available models at present; additional constraints on $\mathrm{N}$ inputs and climate and soil databases could help to reduce uncertainties in the model.

Finally, our estimates of $\mathrm{N}$ loss fractions have implications for a rapidly changing $\mathrm{N}$ cycle. Nitrogen deposition is on the rise and will continue to rise in the future, spreading rapidly into tropical ecosystems globally (Galloway et al., 2008). Our results suggest that $\mathrm{N}$ inputs into tropical environments and arid sites will disproportionately mobilize to atmospheric gases when compared to extra-tropical moist environments, particularly boreal and temperate forests. Rising levels of $\mathrm{N}$ deposition to tropical ecosystems could release more $\mathrm{N}_{2} \mathrm{O}$ from soils to the atmosphere (see also Matson et al. (1999)), warming the climate in a way that is fundamentally different than what has already been observed for $\mathrm{N}$ deposition effects at the higher latitudes.

\section{Supplementary material related to this article is available online at: http://www.biogeosciences.net/9/ 3287/2012/bg-9-3287-2012-supplement.pdf.}

Acknowledgements. Funded by the Andrew W. Mellon Foundation, financial support from Key Program of the Chinese Academy of Sciences Project KZCX2-YW-BR-20 and NSFC Grant 31100326 to EB, and Department of Climate Change, Australia to YPW.

Edited by: R. Conant

\section{References}

Altabet, M. A., Francois, R., Murray, D. W., and Prell, W. L.: Climate-related variations in denitrification in the Arabian Sea from sediment ${ }^{15} \mathrm{~N} /{ }^{14} \mathrm{~N}$ ratios, Nature, 373, 506-509, 1995.

Amundson, R. and Baisden, W. T.: Stable isotope tracers and models in soil organic matter studies, in: Methods in Ecosystem Science, edited by: Sala, O., Mooney, H., Howarth, B., and Jackson, R. B., Springer Verlag, New York, NY, 117-137, 2000.
Amundson, R., Austin, A. T., Schuur, E. A. G., Yoo, K., Matzek, V., Kendall, C., Uebersax, A., Brenner, D., and Baisden, W. T.: Global patterns of the isotopic composition of soil and plant nitrogen, Global Biogeochem. Cy., 17, 1031, doi:1010.1029/2002GB001903, 2003.

Aranibar, J. N., Macko, S. A., Anderson, I. C., Potgieter, A. L. F., Sowry, R., and Shugart, H. H.: Nutrient cycling responses to fire frequency in the Kruger National Park (South Africa) as indicated by stable isotope analysis, Isotopes in Environmental Health Studies, 39, 141-158, 2003.

Bai, E. and Houlton, B. Z.: Coupled isotopic and process-based modeling of gaseous nitrogen losses from tropical rain forests, Global Biogeochem. Cy., 23, doi:10.1029/2008GB003361, 2009.

Bakwin, P. S., Wofsy, S. C., Fan, S.-M., Keller, M., Trumbore, S. E., and Da Costa, J. M.: Emission of nitric oxide (NO) from tropical forest soils and exchange of NO between the forest canopy and atmospheric boundary layers, J. Geophys. Res., 95, 1675516764, 1990.

Bateman, E. J., and Baggs, E. M.: Contributions of nitrification and denitrification to $\mathrm{N}_{2} \mathrm{O}$ emissions from soils at different waterfilled pore space, Biol. Fertil. Soils, 41, 379-388, 2005.

Boddey, R. M., Peoples, M. B., Palmer, B., and Dart, P. J.: Use of the ${ }^{15} \mathrm{~N}$ natural abundance technique to quantify biological nitrogen fixation by woody perennials, Nutr. Cycl. Agroecosyst., 57, 235270, 2000.

Bouwman, A. F., Van der Hoek, K. W., and Olivier, J. G. J.: Uncertainties in the global source distribution of nitrous oxide, J. Geophys. Res., 100, 2785-2800, 1995.

Bouwman, A. F., Lee, D. S., Asman, W. A. H., Dentener, F. J., Van Der Hoek, K. W., and Olivier, J. G. J.: A global high-resolution emission inventory for ammonia, Global Biogeochem. Cy., 11, 561-587, 1997.

Bouwman, A. F., Deecht, G. V., and Hoek, K. W. V. d.: Global and regional surface nitrogen balances in intensive agricultural production eystems for the period 1970-2030, Pedosphere, 15, 19, 2005a.

Bouwman, A. F., Van Drecht, G., Knoop, J. M., Beusen, A. H. W., and Meinardi, C. R.: Exploring changes in river nitrogen export to the world's oceans, Global Biogeochem. Cy., 19, doi:10.1029/2004GB002314, 2005b.

Bowden, W.: Gaseous nitrogen emissions from undisturbed terrestrial ecosystems: an assessment of their impacts on local and global nitrogen budgets, Biogeochemistry, 2, 249-279, 1986.

Boyer, E. W., Alexander, R. B., Parton, W. J., Li, C., ButterbachBahl, K., Donner, S. D., Skaggs, R. W., and Del Grosso, S. J.: Modeling denitrification in terrestrial and aquatic ecosystems at regional scales, Ecol. Appl., 16, 2123-2142, 2006.

Brenner, D. L., Amundson, R., Baisden, W. T., Kendall, C., and Harden, J.: Soil $\mathrm{N}$ and ${ }^{15} \mathrm{~N}$ variation with time in a California annual grassland ecosystem, Geochim. Cosmochim. Acta, 65, 4171-4186, 2001.

Butterbach-Bahl, K., Willibald, G., and Papen, H.: Soil core method for direct simultaneous determination of $\mathrm{N}_{2}$ and $\mathrm{N}_{2} \mathrm{O}$ emissions from forest soils, Plant. Soil., 240, 105-116, 2002.

Buzek, F., Cerny, J., and Paces, T.: The behavior of nitrogen isotopes in acidified forest soils in the Czech Republic, Water, Air, and Soil Pollution, 105, 155-164, 1998. 
Charria, G., Dadou, I., Llido, J., Drévillon, M., and Garçon, V.: Importance of dissolved organic nitrogen in the north Atlantic Ocean in sustaining primary production: a 3-D modelling approach, Biogeosciences, 5, 1437-1455, doi:10.5194/bg-5-14372008, 2008.

Cleveland, C. C., Townsend, A. R., Schimel, D. S., Fisher, H., Howarth, R. W., Hedin, L. O., Perakis, S. S., Latty, E. F., Von Fischer, J. C., Elseroad, A., and Wasson, M. F.: Global patterns of terrestrial biological nitrogen $\left(\mathrm{N}_{2}\right)$ fixation in natural ecosystems, Global Biogeochem. Cy., 13, 623-645, 1999.

Cornell, S., Rendell, A., and Jickells, T.: Atmospheric inputs of dissolved organic nitrogen to the oceans, Nature, 376, 243-246, 1995.

Craine, J. M., Elmore, A. J., Aidar, M. P. M., Bustamante, M., Dawson, T. E., Hobbie, E. A., Kahmen, A., Mack, M. C., McLauchlan, K. K., Michelsen, A., Nardoto, G. B., Pardo, L. H., Penuelas, J., Reich, P. B., Schuur, E. A. G., Stock, W. D., Templer, P. H., Virginia, R. A., Welker, J. M., and Wright, I. J.: Global patterns of foliar nitrogen isotopes and their relationships with climate, mycorrhizal fungi, foliar nutrient concentrations, and nitrogen availability, New Phytol., 183, 980-992, 2009.

Dalal, R. C. and Allen, D. E.: Turner Review No. 18. Greenhouse gas fluxes from natural ecosystems, Aust. J. Bot., 56, 369-407, doi:10.1071/BT07128, 2008.

Dannenmann, M., Butterbach-Bahl, K., Gasche, R., Willibald, G., and Papen, H.: Dinitrogen emissions and the $\mathrm{N}_{2}: \mathrm{N}_{2} \mathrm{O}$ emission ratio of a Rendzic Leptosol as influenced by $\mathrm{pH}$ and forest thinning, Soil Biol. Biochem., 40, 2317-2323, 2008.

Davidson, E. A.: Fluxes of nitrous oxide and nitric oxide from terrestrial ecosystems, in: Microbial production and consumption of greenhouse gases: methane, nitrogen oxides, and halomethanes, edited by: Rogers, J. E., and Whitman, W. B., American Society for Microbiology, Washington, D.C., USA, 219-235, 1991.

Davidson, E. A. and Kingerlee, W.: A global inventory of nitric oxide emissions from soils, Nutr. Cycl. Agroecosyst., 48, 37-50, 1997.

Denman, K. L., Brasseur, G., Chidthaisong, A., Ciais, P., Cox, P. M., Dickinson, R. E., Hauglustaine, D., Heinze, C., Holland, E., Jacob, D., Lohmann, U., Ramachandran, S., Dias, P. L. d. S., Wofsy, S. C., and Zhang, X.: Couplings Between Changes in the Climate System and Biogeochemistry, in: Climate Change 2007: The Physical Science Basis. Contribution of Working Group I to the Fourth Assessment Report of the Intergovernmental Panel on Climate Change, edited by: Solomon, S., Qin, D., Manning, M., Chen, Z., Marquis, M., Averyt, K. B., M.Tignor, and Miller, H. L., Cambridge University Press, Cambridge, UK, 500-587, 2007.

Densmore, J. N., and Böhlke, J. K.: Use of nitrogen isotopes to determine sources of nitrate contamination in two desert basins in California, in: Interdisciplinary perspectives on drinking water risk assessment and management, edited by: Reichard, E. G., Hauchman, F. S., and Sancha, A. M., International Association of Hydrologic Sciences Publication Santiago, Chile, 63-73, 2000.

Deutsch, C., Sarmiento, J. L., Sigman, D. M., Gruber, N., and Dunne, J. P.: Spatial coupling of nitrogen inputs and losses in the ocean, Nature, 445, 163-167, 2007.

Devol, A. H., Uhlenhopp, A. G., Naqvi, S. W. A., Brandes, J. A., Jayakumar, D. A., Naik, H., Gaurin, S., Codispoti, L. A., and Yoshinari, T.: Denitrification rates and excess nitrogen gas con- centrations in the Arabian Sea oxygen deficient zone, Deep Sea Res. Pt. I, 53, 1533-1547, 2006.

Dumont, E., Harrison, J. A., Kroeze, C., Bakker, E. J., and Seitzinger, S. P.: Global distribution and sources of dissolved inorganic nitrogen export to the coastal zone: Results from a spatially explicit, global model, Global Biogeochem. Cy., 19, doi:10.1029/2005gb002488, 2005.

Ehhalt, D., Prather, M., Dentener, F., Derwent, R., Dlugokencky, E., Holland, E., Isaksen, I., Katima, J., Kirchhoff, V., Matson, P., Midgley, P., Wang, M., Berntsen, T., Bey, I., Brasseur, G., Buja, L., Collins, W. J., Daniel, J., DeMore, W. B., Derek, N., Dickerson, R., Etheridge, D., Feichter, J., Fraser, P., Friedl, R., J. Fuglestvedt, M. G., L. Grenfell, A. Grübler, N. Harris,, D. Hauglustaine, L. H., C. Jackman, D. Jacob, L. Jaeglé, A. Jain, M. Kanakidou, S. Karlsdottir,, M. Ko, M. K., M. Lawrence, J.A. Logan, M. Manning, D. Mauzerall, J. McConnell, L. Mickley,, S Montzka, J. F. M., J. Olivier, K. Pickering, G. Pitari, G.J. Roelofs, H. Rogers, B. Rognerud, S. Smith, S. Solomon, J. S., P. Steele, D. Stevenson, J. Sundet, A. Thompson, M. van Weele,, and R. von Kuhlmann, Y. W., D. Weisenstein, T. Wigley, O. Wild, D. Wuebbles, R. Yantosca: Atmospheric chemistry and greenhouse gases, in: IPCC Report 2001, edited by: Houghton, J. T., Ding, Y., Griggs, D. J., Noguer, M., Linden, P. J. v. d., Dai, X., Maskell, K., and Johnson, C. A., Cambridge University Press, Cambridge, UK, 241-280, 2001.

Evans, R. D.: Physiological mechanisms influencing plant nitrogen isotope composition, Trends Plant Sci., 6, 121-126, 2001.

Fan, Y. and van den Dool, H.: Climate prediction center global monthly soil moisture data set at $0.5^{\circ}$ resolution for 1948 to present, J. Geophys. Res., 109, doi:10.1029/2003JD004345, 2004.

Feuerstein, T. P., Ostrom, P. H., and Ostrom, N. E.: Isotopic biogeochemistry of dissolved organic nitrogen: A new technique and application, Org. Geochem., 27, 363-370, 1997.

Freyer, H. D., Kobel, K., Delmas, R. J., Kley, D., and Legrand, M. R.: First results of ${ }^{15} \mathrm{~N} /{ }^{14} \mathrm{~N}$ ratios in nitrate from alpine and polar ice cores, Tellus B, 48, 93-105, doi:10.1034/j.16000889.1996.00009.x, 1996.

Galbally, I. E., Kirstine, W. V., Meyer, C. P., and Wang, Y. P.: Soilatmosphere trace gas exchange in semiarid and arid zones, J. Environ. Qual., 37, 599-607, doi:10.2134/jeq2006.0445, 2008.

Galloway, J. N., Dentener, F. J., Capone, D. G., Boyer, E. W., Howarth, R. W., Seitzinger, S. P., Asner, G. P., Cleveland, C. C., Green, P. A., Holland, E. A., Karl, D. M., Michaels, A. F., Porter, J. H., Townsend, A. R., and Vöosmarty, C. J.: Nitrogen cycles: past, present, and future, Biogeochemistry, 70, 153-226, 2004.

Groffman, P., Butterbach-Bahl, K., Fulweiler, R., Gold, A., Morse, J., Stander, E., Tague, C., Tonitto, C., and Vidon, P.: Challenges to incorporating spatially and temporally explicit phenomena (hotspots and hot moments) in denitrification models, Biogeochemistry, 93, 49-77, 2009.

Handley, L. L., Austin, A. T., Robinson, D., Scrimgeour, C. M., Raven, J. A., Heaton, T. H. E., Schmidt, S., and Stewart, G. R.: The ${ }^{15} \mathrm{~N}$ natural abundance $\left(\delta^{15} \mathrm{~N}\right)$ of ecosystem samples reflects measures of water availability, Aust. J. Plant Physiol., 26, 185199, 1999.

Hartley, A. E., and Schlesinger, W. H.: Environmental controls on nitric oxide emission from northern Chihuahuan desert soils, Biogeochemistry, 50, 279-300, 2000. 
Heaton, T. H. E., Spiro, B., Madeline, S., and Robertson, C.: Potential canopy influences on the isotopic composition of nitrogen and sulphur in atmospheric deposition, Oecologia, 109, 600-607, 1997.

Hedin, L. O., Vitousek, P. M., and Matson, P. A.: Nutrient losses over four million years of tropical forest development, Ecology, 84, 2231-2255, 2003.

Hedin, L. O., Brookshire, E. N. J., Menge, D. N. L., and Barron, A.: The nitrogen paradox in tropical forest ecosystems, Annual Review of Ecology, Evolution, and Systematics, 40, doi:10.1146/annurev.ecolsys.37.091305.110246, 2009.

Hirsch, A. I., Michalak, A. M., Bruhwiler, L. M., Peters, W., Dlugokencky, E. J., and Tans, P. P.: Inverse modeling estimates of the global nitrous oxide surface flux from 1998-2001, Global Biogeochem. Cy., 20, doi:10.1029/2004GB002443,2006.

Hobbie, J. E. and Hobbie, E. A.: ${ }^{15} \mathrm{~N}$ in symbiotic fungi and plants estimates nitrogen and carbon flux rates in Arctic tundra, Ecology, 87, 816-822, 2006.

Hogberg, P.: Tansley Review No. $95 .{ }^{15} \mathrm{~N}$ natural abundance in soilplant Systems, New Phytol., 137, 179-203, 1997.

Houlton, B. Z., Sigman, D. M., and Hedin, L. O.: Isotopic evidence for large gaseous nitrogen losses from tropical rainforests, Proceedings of the National Academy of Sciences, 103, 8745-8750, doi:10.1073/pnas.0510185103, 2006.

Houlton, B. Z., Sigman, D. M., Schuur, E. A., and Hedin, L. O.: A climate-driven switch in plant nitrogen acquisition within tropical forest communities, Proc. Natl. Acad. Sci. USA., 104, 89028906, 2007.

Houlton, B. Z., Wang, Y.-P., Vitousek, P. M., and Field, C. B.: A unifying framework for dinitrogen fixation in the terrestrial biosphere, Nature, 454, 327-330, 2008.

Houlton, B. Z. and Bai, E.: Imprint of denitrifying bacteria on the global terrestrial biosphere, Proceedings of the National Academy of Sciences, 106, 21713-21716, 2009.

Howarth, R., Billen, G., Swaney, D., Townsend, A., Jaworski, N., Lajtha, K., Downing, J., Elmgren, R., Caraco, N., Jordan, T., Berendse, F., Freney, J., Kudeyarov, V., Murdoch, P., and ZhaoLiang, Z.: Regional nitrogen budgets and riverine N \& P fluxes for the drainages to the North Atlantic Ocean: Natural and human influences, Biogeochemistry, 35, 75-139, 1996.

Huang, J., Dool, H. v. d., and Georgakakos, L. P.: Analysis of model-calculated soil moisture over the United States (1931-93) and application to long-range temperature forecasts, J. Climate, 9, 1350-1362, 1996.

Huang, J., Golombek, A., Prinn, R., Weiss, R., Fraser, P., Simmonds, P., Dlugokencky, E. J., Hall, B., Elkins, J., Steele, P., Langenfelds, R., Krummel, P., Dutton, G., and Porter, L.: Estimation of regional emissions of nitrous oxide from 1997 to 2005 using multinetwork measurements, a chemical transport model, and an inverse method, J. Geophys. Res., 113, doi:10.1029/2007JD009381, 2008.

Isaaks, E. H., and Srivastava, R. M.: An introduction to applied geostatistics, Oxford University Press, New York, New York, USA, 1989.

Jaegle, L., Martin, R. V., Chance, K., Steinberger, L., Kurosu, T. P., Jacob, D. J., Modi, A. I., YobouÃ, V., Sigha-Nkamdjou, L., and Galy-Lacaux, C.: Houltonn-induced nitric oxide emissions from soils, J. Geophys. Res., 109, doi:10.1029/2004JD004787, 2004.
Jinuntuya-Nortman, M., Sutka, R. L., Ostrom, P. H., Gandhi, H., and Ostrom, N. E.: Isotopologue fractionation during microbial reduction of $\mathrm{N}_{2} \mathrm{O}$ within soil mesocosms as a function of waterfilled pore space, Soil Biol. Biochem., 40, 2273-2280, 2008.

Kendall, C.: Tracing nitrogen sources and cycling in catchments, in: Isotope Tracers in Catchment Hydrology, edited by: Kendall, C. and McDonnell, J., Elsevier Sci., New York, 1998.

Lee, D. S., Köhler, I., Grobler, E., Rohrer, F., Sausen, R., GallardoKlenner, L., Olivier, J. G. J., Dentener, F. J., and Bouwman, A. F.: Estimations of global $\mathrm{NO}_{\mathrm{x}}$ emissions and their uncertainties, Atmos. Environ., 31, 1735-1749, 1997.

Lelieveld, J. and Dentener, F. J.: What controls tropospheric ozone?, J. Geophys. Res., 105, 3531-3551, 2000.

Li, C., Frolking, S., and Frolking, T. A.: A model of nitrous oxide evolution from soil driven by rainfall events. I: Model structure and sensitivity, J. Geophys. Res., 97, 9759-9776, 1992.

Liu, Y.: Modelling the emission of nitrous oxide $\left(\mathrm{N}_{2} \mathrm{O}\right)$ and methane $\left(\mathrm{CH}_{4}\right)$ from the terrestrial biosphere to the atmosphere, $\mathrm{PhD}$, MIT joint Program on the Science and Policy of Global Change, Massachusetts Institute of Technology, Cambridge, 219 pp., 1996.

Martinelli, L. A., Piccolo, M. C., Townsend, A. R., Vitousek, P. M., Cuevas, E., McDowell, W., Robertson, G. P., Santos, O. C., and Treseder, K.: Nitrogen stable isotopic composition of leaves and soil: tropical versus temperate forests, Biogeochemistry, 46, 4565, 1999.

Matson, P. A., Vitousek, P. M., and Schimel, D. S.: Regional extrapolation of trace gas flux based on soils and ecosystems, in: Exchange of Trace Gases between Terrestrial Ecosystems and the Atmosphere, edited by: Andreae, M. D., and Schimel, D. S., Springer-Verlag, New York, NY, 97-108, 1989.

Matson, P. A. and Vitousek, P. M.: Ecosystem approach to a global nitrous oxide budget, BioScience, 40, 667-672, 1990.

Matson, P. A., McDowell, W. H., Townsend, A. R., and Vitousek, P. M.: The globalization of $\mathrm{N}$ deposition: ecosystem consequences in tropical environments, Biogeochemistry, 46, 67-83, 1999.

Mayorga, E., Seitzinger, S. P., Harrison, J. A., Dumont, E., Beusen, A. H. W., Bouwman, A. F., Fekete, B. M., Kroeze, C., and Van Drecht, G.: Global nutrient export from watersheds 2 (NEWS 2): Model development and implementation, Environmental Modelling \& Software, 25, 837-853, 2010.

McClain, M. E., Boyer, E. W., Dent, C. L., Gergel, S. E., Grimm, N. B., Groffman, P. M., Hart, S. C., Harvey, J. W., Johnston, C. A., Mayorga, E., McDowell, W. H., and Pinay, G.: Biogeochemical hot spots and hot moments at the interface of terrestrial and aquatic ecosystems, Ecosystems, 6, 301-312, 2003.

Merrill, A. G. and Zak, D. R.: Factors controlling denitrification rates in upland and swamp forests, Can. J. For. Res., 22, 15971604, 1992.

Mintz, Y. and Serafini, Y.: Global fields of soil moisture and landsurface evapotranspiration, NASA Goddard Space Flight Center Tech. Memo 83907, 178-180, 1981.

Morford, S. L., Houlton, B. Z., and Dahlgren, R. A.: Increased forest ecosystem carbon and nitrogen storage from nitrogen rich bedrock, Nature, 477, 78-81, 2011.

Neff, J. C., Chapin, F. S., and Vitousek, P. M.: Breaks in the cycle: dissolved organic nitrogen in terrestrial ecosystems, Frontiers in Ecology and the Environment, 1, 205-211, doi:10.1890/15409295(2003)001[0205:BITCDO]2.0.CO;2, 2003. 
Nevison, C. D., Esser, G., and Holland, E. A.: A global model of changing $\mathrm{N}_{2} \mathrm{O}$ emissions from natural and perturbed soils, Clim. Change, 32, 327-378, 1996.

Olivier, J. G. J., Bouwman, A. F., Van der Hoek, K. W., and Berdowski, J. J. M.: Global air emission inventories for anthropogenic sources of $\mathrm{NO}_{\mathrm{x}}, \mathrm{NH}_{3}$ and $\mathrm{N}_{2} \mathrm{O}$ in 1990, Environ. Pollut., 102, 135-148, 1998.

Parton, W. J., Hartman, M., Ojima, D., and Schimel, D.: DAYCENT and its land surface submodel: description and testing, Global and Planetary Change, 19, 35-48, 1998.

Potter, C. S., Matson, P. A., Vitousek, P. M., and Davidson, E. A.: Process modeling of controls on nitrogen trace gas emissions from soils worldwide, J. Geophys. Res., 101, 1361-1377, 1996.

Rastetter, E. B., Perakis, S. S., Shaver, G. R., and Agren, G. I.: Terrestrial $\mathrm{C}$ sequestration at elevated $\mathrm{CO}_{2}$ and temperature: the role of dissolved organic $\mathrm{N}$ loss, Ecol. Appl., 15, 71-86, doi:10.1890/03-5303, 2005.

Ravishankara, A. R., Daniel, J. S., and Portmann, R. W.: Nitrous oxide $\left(\mathrm{N}_{2} \mathrm{O}\right)$ : the dominant ozone-depleting substance emitted in the 21st century, Science, 326, 123-125, doi:10.1126/science.1176985, 2009.

Saxton, K. E., Rawls, W. J., Romberger, J. S., and Papendick, R. I.: Estimating generalized soil-water characteristics from texture, Soil Sci. Soc. Am. J., 50, 1031-1036, 1986.

Schaldac, R. and Pries, J. A.: Integrated Models of the Land System: A Review of Modelling Approaches on the Regional to Global Scale, Living Reviews in Landscape Research, 2, 1-34, 2008.

Scheer, C., Wassmann, R., Butterbach-Bahl, K., Lamers, J., and Martius, C.: The relationship between $\mathrm{N}_{2} \mathrm{O}, \mathrm{NO}$, and $\mathrm{N}_{2}$ fluxes from fertilized and irrigated dryland soils of the Aral Sea Basin, Uzbekistan, Plant. Soil., 314, 273-283, 2009.

Schlesinger, W. H.: On the fate of anthropogenic nitrogen, Proceedings of the National Academy of Sciences, 106, 203-208, doi:10.1073/pnas.0810193105, 2009.

Scholefield, D., Hawkins, J. M. B., and Jackson, S. M.: Development of a helium atmosphere soil incubation technique for direct measurement of nitrous oxide and dinitrogen fluxes during denitrification, Soil Biol. Biochem., 29, 1345-1352, 1997.

Seitzinger, S., Harrison, J. A., Böhlke, J. K., Bouwman, A. F., Lowrance, R., Peterson, B., Tobias, C., and Drecht, G. V.: Denitrification across landscapes and waterscapes: a synthesis, Ecol. Appl., 16, 2064-2090, 2006.

Shearer, G. and Kohl, D.: $\mathrm{N}_{2}$-Fixation in field settings: estimations based on natural ${ }^{15} \mathrm{~N}$ abundance, Funct. Plant Biol., 13, 699-756, doi:10.1071/PP9860699, 1986.

Shi, S. L., Xing, G. X., Zhou, K. Y., Cao, Y. C., and Yang, W. X.: Natural nitrogen-15 abundance of ammonium nitrogen and fixed ammonium in soils, Pedosphere, 2, 265-272, 1992.

Sigman, D. M., Robinson, R., Knapp, A. N., van Geen, A., McCorkle, D. C., Brandes, J. A., and Thunell, R. C.: Distinguishing between water column and sedimentary denitrification in the Santa Barbara Basin using the stable isotopes of nitrate, Geochemistry, Geophysics, Geosystems 4, 1040, doi:1010.1029/2002GC000384, 2003.

Sokolov, A. P., Kicklighter, D. W., Melillo, J. M., Felzer, B. S., Schlosser, C. A., and Cronin, T. W.: Consequences of considering carbon-nitrogen interactions on the feedbacks between climate and the terrestrial carbon cycle, J. Climate, 21, 3776-3796, doi:10.1175/2008jcli2038.1, 2008.
Stehfest, E. and Bouwman, L.: $\mathrm{N}_{2} \mathrm{O}$ and $\mathrm{NO}$ emission from agricultural fields and soils under natural vegetation: summarizing available measurement data and modeling of global annual emissions, Nutr. Cycl. Agroecosyst., 74, 207-228, 2006.

Sutka, R. L., Ostrom, N. E., Ostrom, P. H., Breznak, J. A., Gandhi, H., Pitt, A. J., and Li, F.: Distinguishing nitrous oxide production from nitrification and denitrification on the basis of isotopomer abundances, Appl. Environ. Microbiol., 72, 638-644, doi:10.1128/aem.72.1.638-644.2006, 2006.

Swerts, M., Uytterhoeven, G., Merckx, R., and Vlassak, K.: Semicontinuous measurement of soil atmosphere gases with gas-glow soil core method, Soil Sci. Soc. Am. J., 59, 1336-1342, 1995.

Thornton, P. E., Doney, S. C., Lindsay, K., Moore, J. K., Mahowald, N., Randerson, J. T., Fung, I., Lamarque, J.-F., Feddema, J. J., and Lee, Y.-H.: Carbon-nitrogen interactions regulate climate-carbon cycle feedbacks: results from an atmosphereocean general circulation model, Biogeosciences, 6, 2099-2120, doi:10.5194/bg-6-2099-2009, 2009.

Vitousek, P. M.: Litterfall, Nutrient Cycling, and Nutrient Limitation in Tropical Forests, Ecology, 65, 285-298, doi:10.2307/1939481, 1984.

Wang, Y.-P. and Houlton, B. Z.: Nitrogen constraints on terrestrial carbon uptake: Implications for the global carbon-climate feedback, Geophys. Res. Lett., 36, doi:10.1029/2009g1041009, 2009.

Wang, Y. P., Houlton, B. Z., and Field, C. B.: A model of biogeochemical cycles of carbon, nitrogen, and phosphorus including symbiotic nitrogen fixation and phosphatase production, Global Biogeochem. Cy., 21, doi:10.1029/2006GB002797, 2007.

Wang, Y. P., Law, R. M., and Pak, B.: A global model of carbon, nitrogen and phosphorus cycles for the terrestrial biosphere, Biogeosciences, 7, 2261-2282, doi:10.5194/bg-7-2261-2010, 2010.

Wellman, R. P., Cook, F. D., and Krouse, H. R.: Nitrogen-15: microbiological alteration of abundance, Science, 161, 269-270, doi:10.1126/science.161.3838.269, 1968.

Whitehead, P. G., Wilson, E. J., and Butterfield, D.: A semidistributed ntegrated itrogen model for multiple source assessment in tchments (INCA): Part I - model structure and process equations, Sci. Total Environ., 210-211, 547-558, 1998.

Williams, J. R., Jones, C. A., and Dyke, P. T.: A modeling approach to determining the relationship between erosion and soil productivity, Transactions of the ASAE 17, 129-144, 1984.

Willmott, C. J. and Matsuura, K.: Terrestrial Air Temperature and Precipitation: Monthly and Annual Climatologies, Version 3.01, 2000.

Wolf, I. and Brumme, R.: Dinitrogen and nitrous oxide formation in beech forest floor and mineral soils, Soil Sci. Soc. Am. J., 67, 1862-1868, 2003.

$\mathrm{Xu}, \mathrm{X}$. , Tian, H., and Hui, D.: Convergence in the relationship of $\mathrm{CO}_{2}$ and $\mathrm{N}_{2} \mathrm{O}$ exchanges between soil and atmosphere within terrestrial ecosystems, Glob. Change Biol., 14, 1651-1660, 2008.

Yan, X., Ohara, T., and Akimoto, H.: Statistical modeling of global soil $\mathrm{NO}_{\mathrm{x}}$ emissions, Global Biogeochem. Cy., 19, doi:10.1029/2004GB002276, 2005.

Yienger, J. J. and Levy, H., II: Empirical model of global soilbiogenic $\mathrm{NO}_{\mathrm{x}}$ emissions, J. Geophys. Res. Atmos., 100, 114470 11464, 1995.

Yoneyama, T., Fujita, K., Yoshida, T., Matsumoto, T., Kambayashi, I., and Yazaki, J.: Variation in natural abundance of ${ }^{15} \mathrm{~N}$ among plant parts and in ${ }^{15} \mathrm{~N} /{ }^{14} \mathrm{~N}$ fractionation during $\mathrm{N}_{2}$ fixation in 
the legume-rhizobia symbiotic system, Plant. Cell. Physiol., 27, 791-799, 1986.

Yoshida, $\mathrm{N} .:{ }^{15} \mathrm{~N}$-depleted $\mathrm{N}_{2} \mathrm{O}$ as a product of nitrification, Nature, 335, 528-529, 1988.

Zaehle, S., Friedlingstein, P., and Friend, A. D.: Terrestrial nitrogen feedbacks may accelerate future climate change, Geophys. Res. Lett., 37, L01401, 2010a.
Zaehle, S., Friend, A. D., Friedlingstein, P., Dentener, F., Peylin, P., and Schulz, M.: Carbon and nitrogen cycle dynamics in the O$\mathrm{CN}$ land surface model: 2. Role of the nitrogen cycle in the historical terrestrial carbon balance, Global Biogeochem. Cy., 24, GB1006, 2010b. 